\title{
Common Rail Direct Injection Mode of CI Engine Operation with Different Injection Strategies - A Method to Reduce Smoke and NOx Emissions Simultaneously
}

\author{
S. V. Khandal ${ }^{1}$, Nagaraj R. Banapurmath ${ }^{1 *}$, V. N. Gaitonde ${ }^{1}$, Virupaxappa S. Yaliwal ${ }^{2}$ \\ ${ }^{1}$ B. V. B. College of Engineering and Technology, Hubballi, Karnataka, INDIA \\ ${ }^{2}$ Department of Mechanical Engineering, S. D. M. College of Engineering and Technology, Dharwad, Karnataka, INDIA
}

*Corresponding Author: nrbanapurmath@gmail.com

Citation: Khandal, S. V., Banapurmath, N. R., Gaitonde, V. N. and Yaliwal, V. S. (2018). Common Rail Direct Injection Mode of CI Engine Operation with Different Injection Strategies - A Method to Reduce Smoke and NOx Emissions Simultaneously. European Journal of Sustainable Development Research, 2(2), 15. https://doi.org/10.20897/ejosdr/76884

Published: March 7, 2018

\begin{abstract}
Compression ignition (CI) engines are most efficient and robust prime movers used in transportation, power generation applications but suffer from the problems of higher level of exhaust smoke and $\mathrm{NO}_{\mathrm{x}}$ tailpipe emissions with increased use of fossil fuels. Alternative fuel that replaces diesel and at the same time that result in lower smoke and $\mathrm{NO}_{\mathrm{x}}$ emissions is presently needed. Therefore the main aim of this experimental study is to lower the smoke and $\mathrm{NO}_{\mathrm{x}}$ emissions and to use non edible oils that replace the diesel. For this locally available honge biodiesel (BHO) and cotton seed biodiesel (BCO) were selected as alternative fuels to power $\mathrm{CI}$ engine operated in common rail direct injection (CRDI) mode. In the first part, optimum fuel injection timing (IT) and injection pressure (IP) for maximum engine brake thermal efficiency (BTE) was obtained. In the second part, performance, combustion and emission characteristics of the CRDI engine was studied with two different fuel injectors having 6 and 7 holes each having $0.2 \mathrm{~mm}$ orifice diameter. The CRDI engine results obtained were compared with the baseline date reported. The combustion chamber (CC) used for the study was toroidal re-entrant (TRCC). The experimental tests showed that BHO and BCO fuelled CRDI engine showed overall improved performance with 7 hole injector when engine was operated at optimized fuel IT of $10^{\circ}$ before top dead centre (bTDC) and IP of $900 \mathrm{bar}$. The smoke emission reduced by $20 \%$ to $26 \%$ and $\mathrm{NO}_{\mathrm{x}}$ reduced by $16 \%$ to $20 \%$ in diesel and biodiesel powered CRDI engine as compared to conventional CI mode besides replacing diesel by biodiesel fuel (BDF).
\end{abstract}

Keywords: honge biodiesel (BHO), cotton seed biodiesel (BCO), common rail direct injection (CRDI) engine, number of holes

\section{INTRODUCTION}

The need for alternative and renewable fuel like BDF in place of depleting diesel fuel demands higher IP due to their higher viscosity. The conventional CI engine has the limitation of fuel IP which can be overcome by employing CRDI facility which injects fuel at any CA, duration and IP. Performance, emission and combustion characteristics study on CRDI engine on rape seed oil methyl ester (ROME) and its blend with diesel showed lower smoke, $\mathrm{CO}$ and $\mathrm{HC}$ emissions with higher $\mathrm{NO}_{\mathrm{x}}$ levels on account of better air fuel mixture prevailed which led to complete combustion (Carlo et al., 2002). Better overall mixing of fuel with air reduced ID with increased fuel droplet velocity and decreased droplet size resulted at higher fuel IP. This led to higher HRR and higher incylinder temperature which resulted in increased engine out $\mathrm{NO}_{\mathrm{x}}$ emissions (Lee and Park; 2002).The mixing process of fuel with air enhanced at higher fuel IP due to higher charge temperature available at high load condition. 
More combustible mixture was formed during ID period because of the higher PP at fuel IP of 900 bar as compared to $800 \mathrm{bar}$. At the same SOI, variation of fuel IP significantly altered the heat release profile, i.e., higher fuel IP led to earlier SOC and higher as well as narrower peak heat release (Ye and Boehman, 2010; Labecki and Ganippa, 2012). A study on the effect of injection parameters on the combustion and emission characteristics of CRDI engine fuelled with waste cooking oil revealed that HRR of BDF gradually increased with advanced fuel IT irrespective of load condition. At high load, the ISFC was higher and reached minimum when the IT was about $10^{\circ}$ aTDC. The HC emissions of the BDF were slightly lower than those of the diesel at the fuel IP of $1600 \mathrm{bar}$, but NOx emissions in the engine out gas were found higher. It was also reported that the CO emissions decreased with higher fuel IP at high load condition when fuel IT was retarded (Joonsik et al., 2014). CRDI engine operated at a constant engine speed of $1800 \mathrm{rpm}$ and different loads of $3.2 \mathrm{bar}$, 5.1 bar IMEP revealed that the control of combustion phasing and EGR of the gasoline/diesel fuels could yield emission lower than CI engine and BTE higher than typical SI engine (Jiakun et al., 2015). The effect of 10\%, 20\% and 50\% Karanja BDF (KOME) blends with diesel were studied on the injection rate, fuel atomization, performance of a CRDI engine at a constant engine speed of $1500 \mathrm{rpm}$ and at different IT. The results showed that with lower blend (20\%) HC and CO emissions were reduced in comparison to mineral diesel. It was also reported that up to B10, CRDI engines showed improved BTE and reduced emissions with no change in hardware (Agarwal et al., 2015). The study on CRDI engine confirmed that engine operation was possible with up to $75 \%$ swine lard methyl esters blend with diesel but with small decrease in brake fuel conversion efficiency and increase in BSFC (Mikulski et al., 2016). The diesel equivalent levels of soot emission and 22\% lower NOx emission were revealed with 30\% RSO at IT of $3^{\circ} \mathrm{bTDC}$ and IP of 1200 bar (Labecki et al., 2012). Soybean BDF indicated faster ignition, lower pre-mixed spike and lower PP when start of energizing was between 2 to $6^{\circ} \mathrm{bTDC}$. For rapeseed BDF with fuel IT varied from 10 to $5^{\circ} \mathrm{bTDC}$ the combustion process occurred nearer to TDC resulting in higher BTE. More efficient utilization of fuel resulting in better atomization and the advancement or retardation in fuel IT from the optimum value is the reason for deterioration of BTE (Ye and Boehman, 2010; Monyem et al., 2001; Senatore et al., 2008). At higher fuel IP the BTE improved due to efficient utilization of fuel because of better atomization (Bakar et al., 2008). As the fuel IP increases from 800 bar to 900 bar the combustion phasing of BDF advances due to the reduction of the ID through better air entrainment and mixing. When the fuel IP is increased ID decreased due to smaller SMD, shorter break up length, higher dispersion and better atomization of injected linolenic linseed oil methyl ester BDF (Puhan et al., 2009). Retarding the fuel IT decreases the PP due to shorter ID resulting in lower peak cylinder gas temperatures which resulted in lower $\mathrm{NO}_{\mathrm{x}}$ concentration (Leung et al., 2006). The smoke emissions of BDF were higher than mineral diesel under the same operating conditions. This could be attributed to the presence of FFA in the BDF leading to poor air-fuel mixture. Smoke emissions of both fuels increased when the IT was retarded due to sluggish and diffusion combustion phase caused by reduced fuel-air mixing rate due to later injection (Sayin et al., 2009). The engine performance with bio fuel-blended diesel fuels (blend range) was similar to that under D100 fuel. Use of BDF-diesel blends lowered the $\mathrm{HC}$ and $\mathrm{CO}$ emissions but showed higher engine out $\mathrm{NO}_{\mathrm{x}}$. The smoke emissions were reduced by $50 \%$ with the use of bio ethanol-diesel blends (Kim and Choi, 2009). The $\mathrm{NO}_{\mathrm{x}}$ emissions drastically increased with increase in fuel IP for the BDF and CO, HC, smoke emissions showed decreasing trend with higher fuel IP at higher loads (Hwang et al., 2014; Armas et al., 2006). The amount of fuel delivered during ID could be increased due to enhanced atomization of fuel at the nozzle outlet with high IP which leads to a more distributed vapour phase and better combustion which facilitates increased premixed HRR especially at higher load condition (Ozsezen et al., 2008; Can et al., 2004). It can be noted that at different fuel IT $\left(20^{\circ} \mathrm{bTDC}\right.$ to $\left.5^{\circ} \mathrm{aTDC}\right)$ the PP and the peak HRR of the BDF are slightly lower than those of the diesel. The PP is increased as the fuel IT was advanced due to increased ID. More homogeneous fuel-air mixture is formed which results in a strong premixed combustion phase leading to a higher PP (Narayana et al., 2016).

From the exhaustive literature survey on CRDI engine, it can be noted that utilization of biodiesel, effect of CC shape and nozzle holes on the performance has been scantily reported. Therefore the objective of this experimental study mainly focusses on the use of biodiesels (BHO and BCO) derived from non-edible oils and test their suitability in CRDI engines along with use of injector with varied number of holes and TRCC shape. Initially the fuel IT and IP for best BTE condition was obtained and then keeping optimum IT and IP, experiments were conducted on the engine with injector having varied number of holes. Finally conclusions were drawn from the experimental study.

\section{EXPERIMENTAL TEST RIG AND PROCEDURE ADOPTED}

The existing CI engine had HCC. The existing $5.2 \mathrm{~kW}$ CI was modified to operate in CRDI mode. In order to facilitate high pressure injection of BDFs in the converted CRDI engine and to facilitate the swirl induced air-fuel mixture the CC was modified to TRCC shape. All the experimental results presented in this study are with TRCC in CRDI mode. The fuel from the tank is pumped to a high pressure CRDI pump through a fuel filter using low 


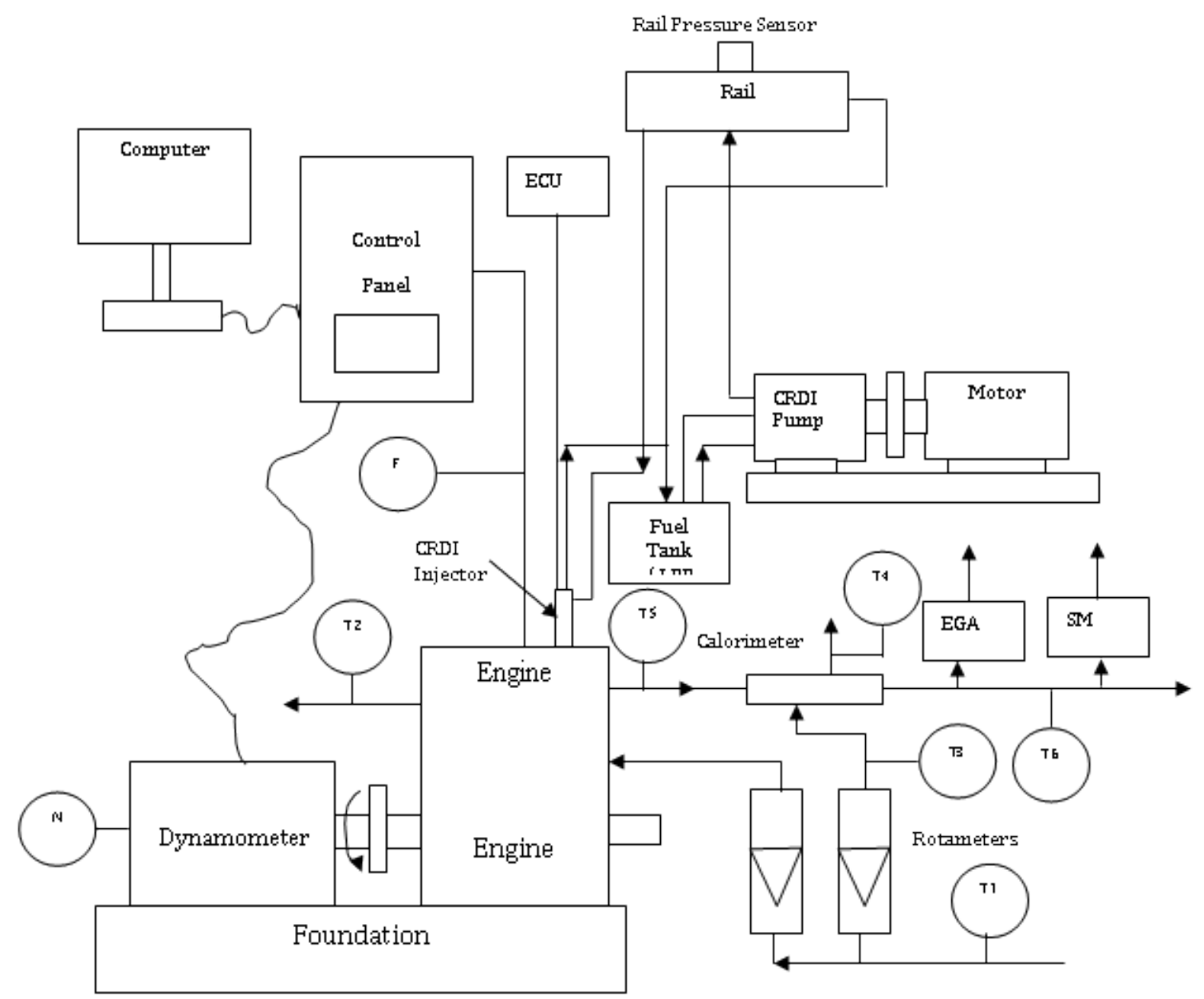

T1, T3 - Inlet Water Temperature, T2 - Outlet Engine Jacket Water Temperature, T4 - Utlet Calorimeter Water Temperature, T5 - Exhaust Gas Temperature before Calorimeter T6 - Exhaust Gas Temperature after Calorimeter, F - Fluid Flow differential pressure Unit, N - Speed Encoder, EGA - Exhaust Gas Analyser, SM - Smoke Meter, LPP-Low pressure pump Figure 1. Schematic of experimental set up with CRDI facility

pressure pump. The variable speed motor regulates the speed of the high pressure pump which controls the quantity of fuel supplied to a common rail. A pressure relief valve controls the amount of pressure required for fuel injection. In house developed calibrated ECU regulates the fuel SOI (IT) and duration. Modified experimental set up with CRDI facility is shown in Figure 1. The experimental tests on CRDI engine were carried out at the engine speed of 1500 RPM for 80 and 100\% loads keeping CR 17.5. The fuel injection rate was adjusted to maintain a constant speed of $1500 \mathrm{rpm}$ for both loads and stable engine condition readings were recorded. The temperature of cooling water at exit was maintained at $70^{\circ} \mathrm{C}$. The experiments were conducted using diesel, $\mathrm{BHO}$ and $\mathrm{BCO}$ fuels with two injectors of 6 and 7 holes. The diameter of both the injector orifices was $0.2 \mathrm{~mm}$. Properties of diesel, $\mathrm{BHO}$ and $\mathrm{BCO}$ are provided in Table 1. Specifications of CI engine test rig used for the experimental study are shown in Table 2. Pressure sensor and thermocouples provided the cylinder pressure and temperature readings respectively. Exhaust gas emissions were recorded from exhaust gas analyser. The smoke emission was recorded by Hartridge smoke meter. Cooling of the engine was done with the circulating water through the jackets of engine block and cylinder head. HRRs were computed as per the procedure laid down in literature (Hayes et al., 1986; Hohenberg, 1979).

The SOC process was taken as the differentiated cylinder pressure variation time data where a sudden rise in the slope at the point of ignition due to the sudden high premixed heat release. The end of combustion process is the point where $90 \%$ of the heat was released (calculated from the cumulative heat release curve). The ID period is the time lag between the SOI and the start of ignition. The SOI was taken based on the IT set in ECU. The start of combustion process was determined from the differentiated cylinder gas pressure variation time data where a sudden rise in the slope at the point of ignition due to the sudden high premixed heat release. The end of combustion process was taken as the point where $90 \%$ of the heat release had occurred (calculated from the cumulative heat release curve). Difference between these two is taken as combustion duration (CD). 
Table 1. Properties of Diesel, $\mathrm{BHO}$ and BCO

\begin{tabular}{clcccccc}
\hline \multirow{2}{*}{ S.No. } & Properties & \multirow{2}{*}{ Diesel } & \multirow{2}{*}{ BHO } & \multirow{2}{*}{ BCO } & \multicolumn{2}{c}{ Standard limits } & \multirow{2}{*}{ ASTM standard } \\
\cline { 5 - 6 } & & & & Min. & Max. & \\
\hline 1 & Viscosity $\left(\mathrm{cSt}\right.$ at $\left.40^{\circ} \mathrm{C}\right)$ & 4.59 & 5.6 & 5.0 & 1.9 & 6 & ASTM D445 \\
\hline 2 & Flash point $\left({ }^{\circ} \mathrm{C}\right)$ & 65 & 163 & 167 & $100-$ & - & ASTM D93 \\
\hline 3 & Calorific Value $(\mathrm{kJ} / \mathrm{kg})$ & 45000 & 36010 & 39648 & - & - & ASTM D5865 \\
\hline 4 & Density $\left(\mathrm{kg} / \mathrm{m}^{3}\right.$ at $\left.15^{\circ} \mathrm{C}\right)$ & 830 & 890 & 885 & 860 & 900 & ASTM D4052 \\
\hline 5 & Cloud Point $\left({ }^{\circ} \mathrm{C}\right)$ & -10 & -2 & -3 & - & - & ASTM D2500 \\
\hline 6 & Pour Point $\left({ }^{\circ} \mathrm{C}\right)$ & -2 & 1 & 2 & - & - & ASTM D97 \\
\hline 7 & Cetane Number & 50 & 42 & 45 & 47 & - & ASTM D613 \\
\hline 8 & Cold Filter Plugging Point $\left({ }^{\circ} \mathrm{C}\right)$ & 4 & 5 & 6 & - & - & ASTM D6371 \\
\hline 9 & Moisture $(\%)$ & 0.02 & 0.02 & 0.02 & - & 0.05 & ASTM D2709 \\
\hline 10 & Carbon Residue $(\%)$ & 0.1 & 0.12 & 0.13 & - & 0.05 & ASTM D4530 \\
\hline
\end{tabular}

Table 2. CI Engine specifications

\begin{tabular}{cll}
\hline S1. No. & Parameter & Specification \\
\hline 1 & Type of engine & Kirloskar make Single cylinder four stroke direct injection diesel engine \\
\hline 2 & Rated power & $5.2 \mathrm{KW} \mathrm{@} 1500 \mathrm{RPM}$ \\
\hline 3 & Cylinder diameter & $87.5 \mathrm{~mm}$ \\
\hline 4 & Stroke length & $110 \mathrm{~mm}$ \\
\hline 5 & Compression ratio & $17.5: 1$ \\
\hline 6 & Software used & Engine soft \\
\hline Air measurement manometer & \\
\hline 7 & Made & MX 201 \\
\hline 8 & Type & U- Type \\
\hline 9 & Range & $100-0-100 \mathrm{~mm}$ \\
\hline Eddy current dynamometer & \\
\hline 10 & Model & AG - 10 \\
\hline 11 & Type & Eddy current \\
\hline 12 & Maximum & $7.5(\mathrm{~kW}$ at $1500-3000 \mathrm{RPM})$ \\
\hline 13 & Flow & Water must flow through Dynamometer during the use \\
\hline 14 & Dynamometer arm length & $0.180 \mathrm{~m}$ \\
\hline
\end{tabular}

Table 3. The accuracies of the measurements and the uncertainties in the calculated parameters

\begin{tabular}{ll}
\hline Measured variable & Accuracy $( \pm)$ \\
\hline Load, $\mathrm{N}$ & 0.1 \\
\hline Engine speed, rpm & 2 \\
\hline Temperature, ${ }^{\circ} \mathrm{C}$ & 1 \\
\hline Measured variable & Uncertainty (\%) \\
\hline Smoke & \pm 1.1 \\
\hline $\mathrm{HC}$ & \pm 1.2 \\
\hline $\mathrm{CO}$ & \pm 2.5 \\
\hline NO ${ }_{\mathrm{x}}$ & \pm 4 \\
\hline Calculated parameters & Uncertainty (\%) \\
\hline BTE $(\%)$ & \pm 1.3 \\
\hline HRR $\left({ }^{\circ} \mathrm{CA}\right)$ & \pm 0.9 \\
\hline
\end{tabular}

\section{Uncertainty analysis of the experimental data}

The accuracies of the measurements and the uncertainties in the calculated parameters of the current investigation are provided in the Table 3. In order to minimize the errors of measurements six readings were recorded and averaged out results are only presented for plotting the graphs and analysis carried out.

\section{RESULTS AND DISCUSSIONS}

The experimental results of CRDI engine are discussed in the following sections. The CI engine was operated at $1500 \mathrm{rpm}$ and a compression ratio of 17.5. The CI engine other operating conditions are provided in Table 4 for diesel and BDFs. The manufacturer specified engine operating conditions for diesel and optimum engine operating conditions for BDFs for better BTE was used to record the readings. The HCC was employed in CI mode of engine operation. The average of six results are reported in the Table 4.

\section{Fuel Injection Timing (IT) Optimization for the Diesel, BDF Powered CRDI Engine}

The effect of fuel IT on the performance was studied first. The fuel IT was varied from $25^{\circ} \mathrm{bTDC}$ to $5^{\circ} \mathrm{aTDC}$ in a step of $5^{\circ} \mathrm{CA}$. 
Table 4. Results of $\mathrm{CI}$ mode of engine operation with diesel $\mathrm{BHO}$ and $\mathrm{BCO}$

\begin{tabular}{|c|c|c|c|}
\hline \multirow{3}{*}{ Characteristic } & \multicolumn{3}{|c|}{ CI Mode of Engine Operation } \\
\hline & \multirow{2}{*}{$\begin{array}{c}\text { Diesel } \\
\text { (IOP: } 205 \text { bar, IT: } 23^{\circ} \text { bTDC } \\
\text { Injector: } 3 \text { hole, } 0.3 \mathrm{~mm} \text { diameter) }\end{array}$} & BHO & BCO \\
\hline & & \multicolumn{2}{|c|}{$\begin{array}{l}\text { (IOP: } 240 \text { bar, IT: } 19^{\circ} \mathrm{bTDC} \\
\text { Injector: } 3 \text { hole, } 0.3 \mathrm{~mm} \text { diameter) }\end{array}$} \\
\hline BTE $(\%)$ & 31.25 & 26.0 & 25.6 \\
\hline Smoke (HSU) & 46 & 60 & 62 \\
\hline $\mathrm{HC}(\mathrm{ppm})$ & 36 & 49 & 50 \\
\hline CO (\% vol.) & 0.13 & 0.154 & 0.156 \\
\hline $\mathrm{NO}_{\mathrm{x}}(\mathrm{ppm})$ & 1095 & 1009 & 1000 \\
\hline $\mathrm{PP}$ (bar) & 74 & 68 & 67 \\
\hline $\mathrm{ID}\left({ }^{\circ} \mathrm{CA}\right)$ & 9.9 & 10.2 & 10.3 \\
\hline $\mathrm{CD}\left({ }^{\circ} \mathrm{CA}\right)$ & 38 & 41 & 42 \\
\hline $\operatorname{HRR}\left(\mathrm{J} /{ }^{\circ} \mathrm{CA}\right)$ & 74 & 72 & 71 \\
\hline
\end{tabular}
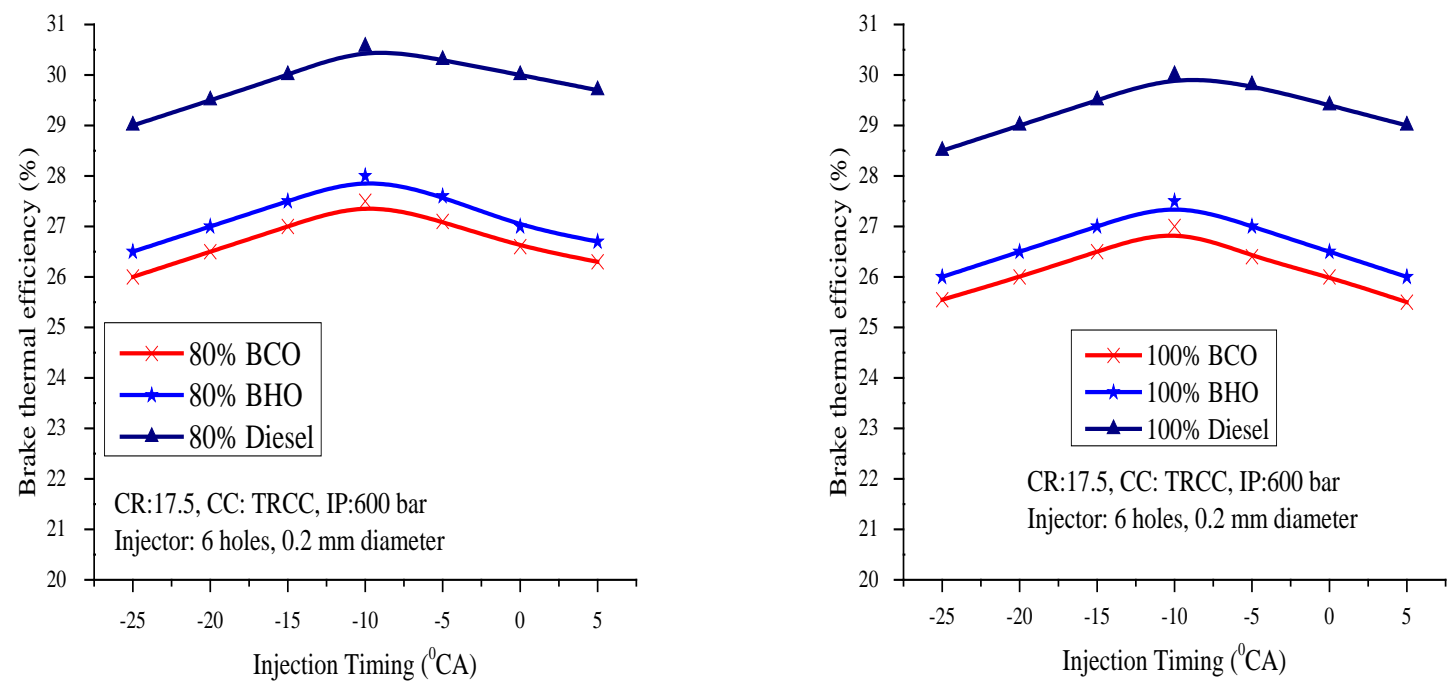

Figure 2. Variation in the BTE at different fuel IT at $80 \%$ load and $100 \%$ load
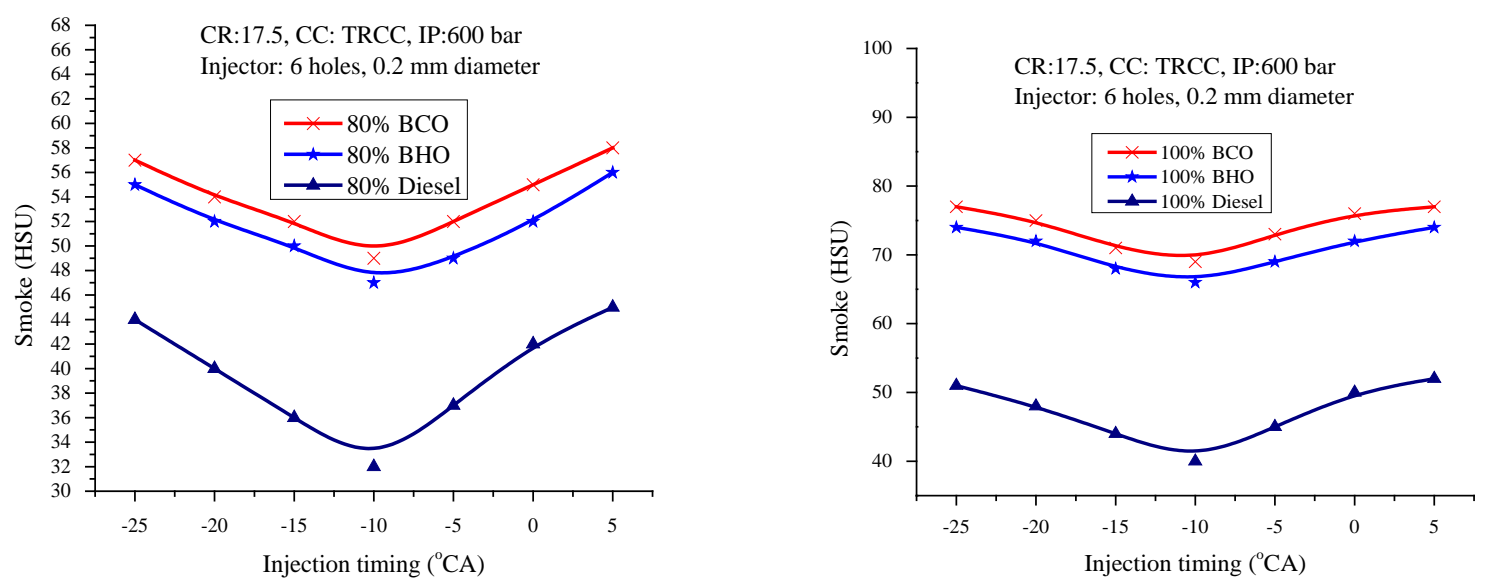

Figure 3. Variation in the smoke emission at different fuel IT at $80 \%$ and $100 \%$ loads

\section{Performance: Brake thermal efficiency}

Figure 2 depictsthe variation in fuel IT on the BTE of CRDI engine fuelled with diesel, BHO and BCO at $80 \%$ and $100 \%$ loads. From Figure 2 it was evidenced that the maximum BTE was resulted at a fuel IT of $10^{\circ}$ bTDC for all fuels. This could be due to better atomization of injected fuel at IP of 600 bar, enhanced air-fuel mixing and reduced wall wetting that led to better burning of fuel. The advancement or retardation from this fuel IT deteriorated the BTE of the CRDI engine. The advanced fuel IT led to wall wetting due to higher fuel IP. On the other hand retarded fuel IT increased fuel entering into crevices and reduced the time available for air fuel mixing. Similar findings were reported in the literature (Can et al., 2004; Hwang et al., 2014; Labecki et al., 2012). Maximum BTE was achieved in the CRDI mode with diesel, $\mathrm{BHO}$ and BCO and were lower by $2.2 \%, 10.4 \%$ and 

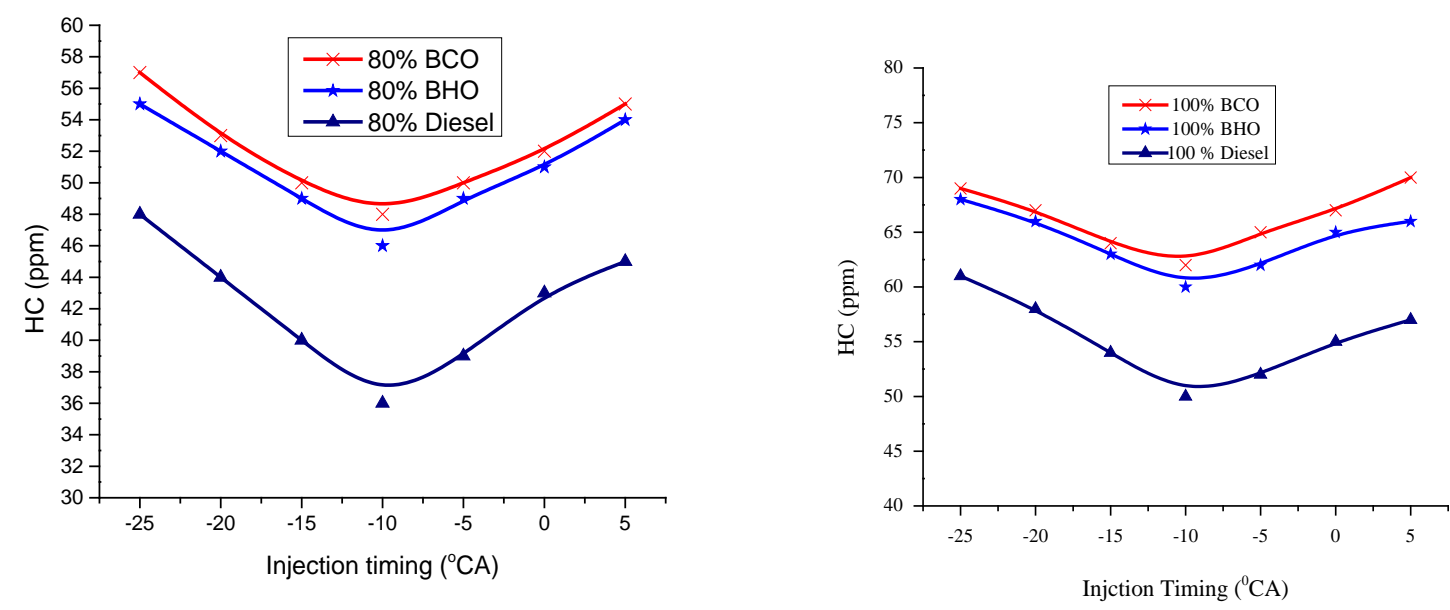

Figure 4. Variation in the HC emission at different fuel IT at $80 \%$ and $100 \%$ loads
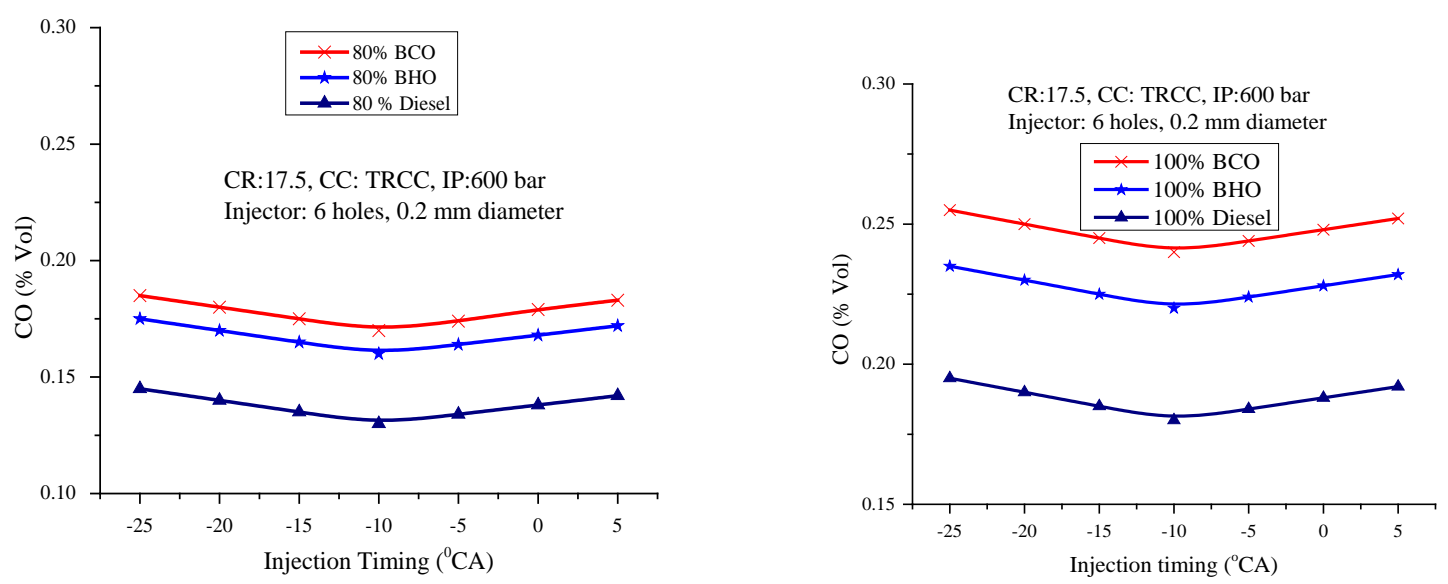

Figure 5. Variation in the CO emission at different fuel IT at $80 \%$ and $100 \%$ loads

$12 \%$ respectively at $80 \%$ load and fuel IT of $10^{\circ}$ bTDC compared to the CI mode. At $100 \%$ load slight reduction in BTE about $2 \%$ was seen for all fuels. BTE of the engine was lower with the BDF as compared to mineral diesel due to their higher viscosity and lower calorific values and also it was observed that BHO showed better BTE as compared to BCO due to its good combustion qualities.

\section{Emissions: Smoke Emission}

Figure 3 shows the effect of change in fuel IT on the engine out smoke emission of CRDI engine fuelled with diesel and BDF used for the study. The smoke emissions in the tail pipe with BDF were higher than the mineral diesel. This could be attributed to the FFA present in the selected BDFs which led to poor air-fuel mixture. At a fuel IP of $600 \mathrm{bar}$, the smoke emissions of all injected fuels decreased up to an IT of $10^{\circ} \mathrm{CA}$ bTDC due to reduced wall wetting and better combustion as more time was available for the oxidation process and beyond which increased trends were observed. Beyond $10^{\circ} \mathrm{CA}$ bTDC sluggish diffusion combustion phase with reduced rate of fuel-air mixing at late injection of fuel was observed. The smoke emission in the exhaust gas of the CRDI engine with BDF were slightly higher by $4 \%$ to $7 \%$ at fuel IT of $10^{\circ} \mathrm{bTDC}, 80 \%$ load and $100 \%$ load as compared to CI mode.

\section{$H C$ and $C O$ Emissions}

Figures 4 and 5 shows the effect of change in the fuel IT on the engine out $\mathrm{HC}$ and $\mathrm{CO}$ emissions of the CRDI engine powered with diesel, $\mathrm{BDF}$ at $80 \%$ and $100 \%$ loads respectively. The $\mathrm{HC}$ and $\mathrm{CO}$ emissions in the engine out gas were lower for the fuel IT of $10^{\circ} \mathrm{bTDC}$. Improved combustion of injected fuel resulted at fuel IP of $600 \mathrm{bar}$ and the higher BTE resulted might be the reason for this result seen. The HC and CO emissions of the engine increased at other fuel ITs. The reason for the result seen could be the advanced IT led to the CC wall wetting and retarded fuel IT increased the fuel entering into the crevices of CC. Similar results were reported in the literature (Agarwal et al., 2015). These emissions level in the exhaust gas with BDF operation were higher compared to mineral diesel operation. The higher viscosity of BDF resulted in to bigger sized fuel droplets at the 

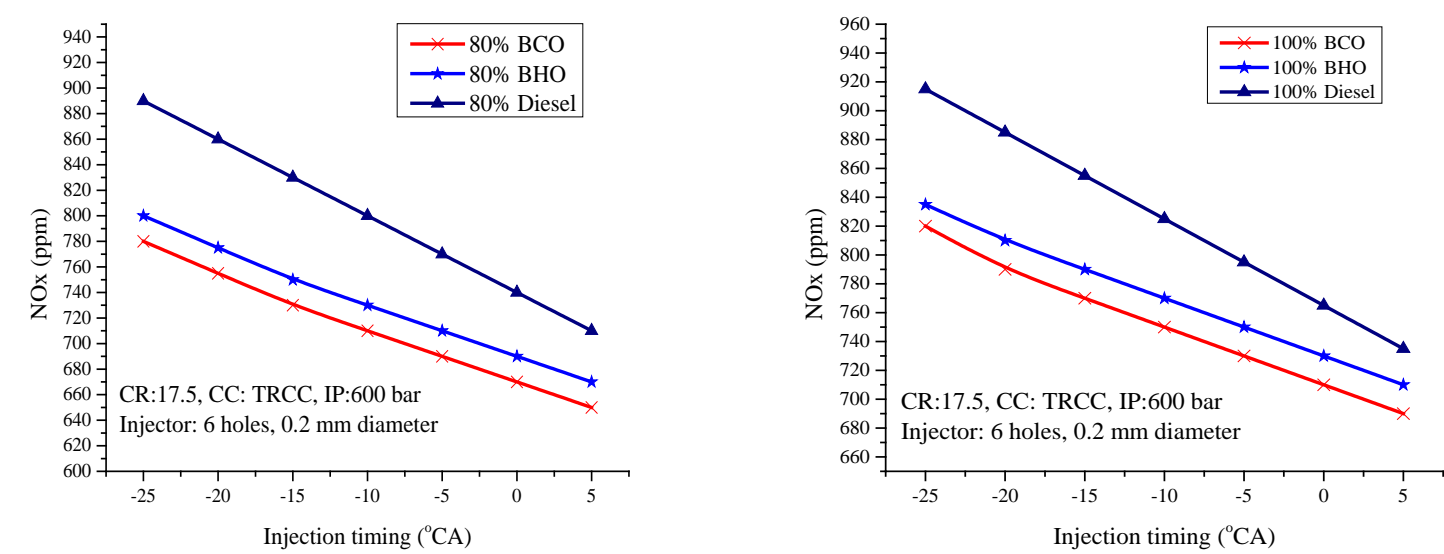

Figure 6. Variation in the $\mathrm{NO}_{\mathrm{x}}$ emission at different fuel IT at $80 \%$ and $100 \%$ loads
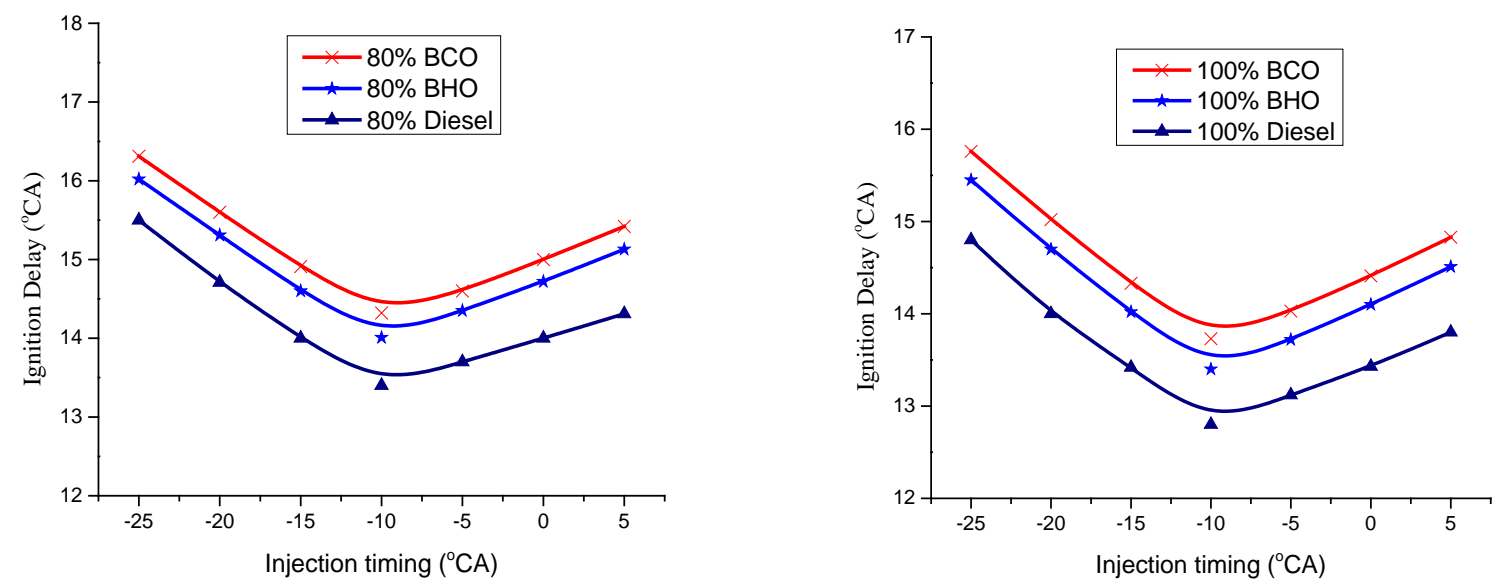

Figure 7. Variation in the ID at different fuel IT at $80 \%$ and $100 \%$ loads
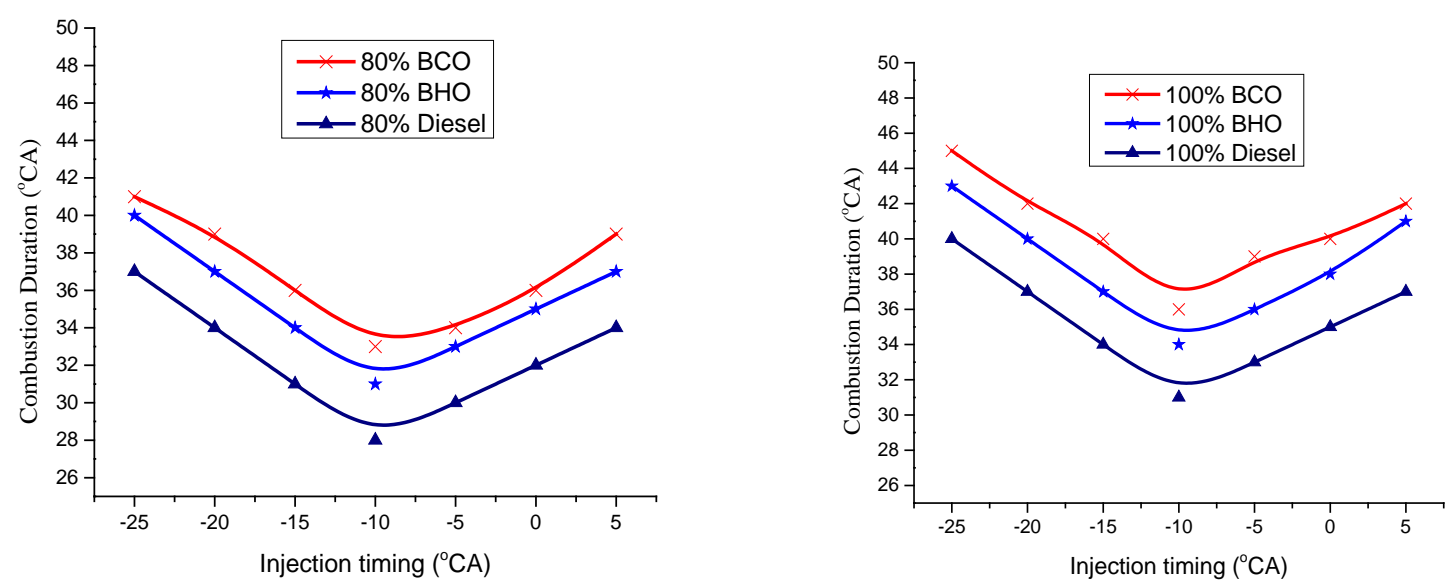

Figure 8. Variation in the CD at different fuel IT at $80 \%$ and $100 \%$ loads

same IP as compared to diesel. Comparatively lower energy density of biodiesel might lead to lowered combustion temperatures which support the results obtained. HC emissions with BDFs were higher by $27 \%$ to $33 \%$ and $15 \%$ to $20 \%$ at $80 \%$ and $100 \%$ load respectively compared to CI mode. Similarly the CO emissions with BDFs were higher by $23 \%$ to $33 \%$ at $80 \%$ load and $100 \%$ load compared to CI mode. BHO yielded slightly lower HC emission as compared to $\mathrm{BCO}$ as it burns better.

\section{$N O_{x}$ Emission}

The effect of change in fuel IT on the emissions of $\mathrm{NO}_{\mathrm{x}}$ with diesel and $\mathrm{BDF}$ at $80 \%$ and $100 \%$ loads is depicted in Figure 6. From Figure 6, it is noted that the $\mathrm{NO}_{\mathrm{x}}$ emission increased with advanced IT. It is well known fact 

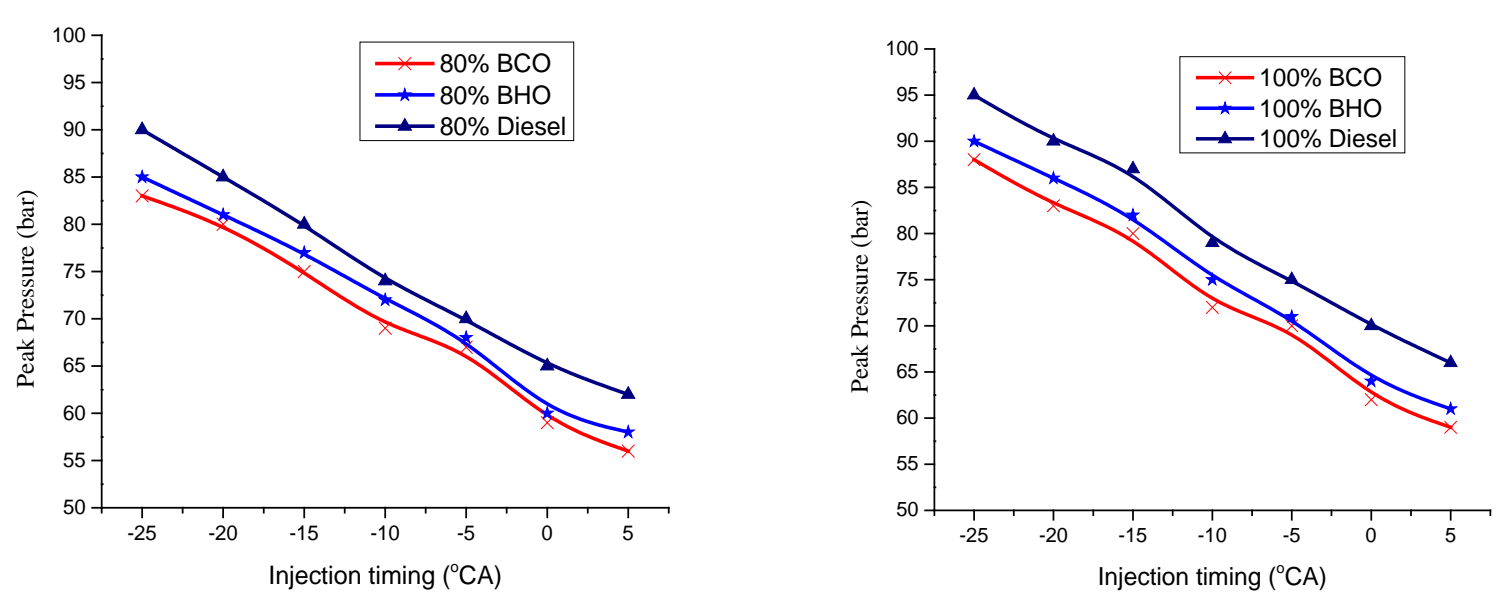

Figure 9. Variation in the PP at different fuel IT at $80 \%$ and $100 \%$ loads
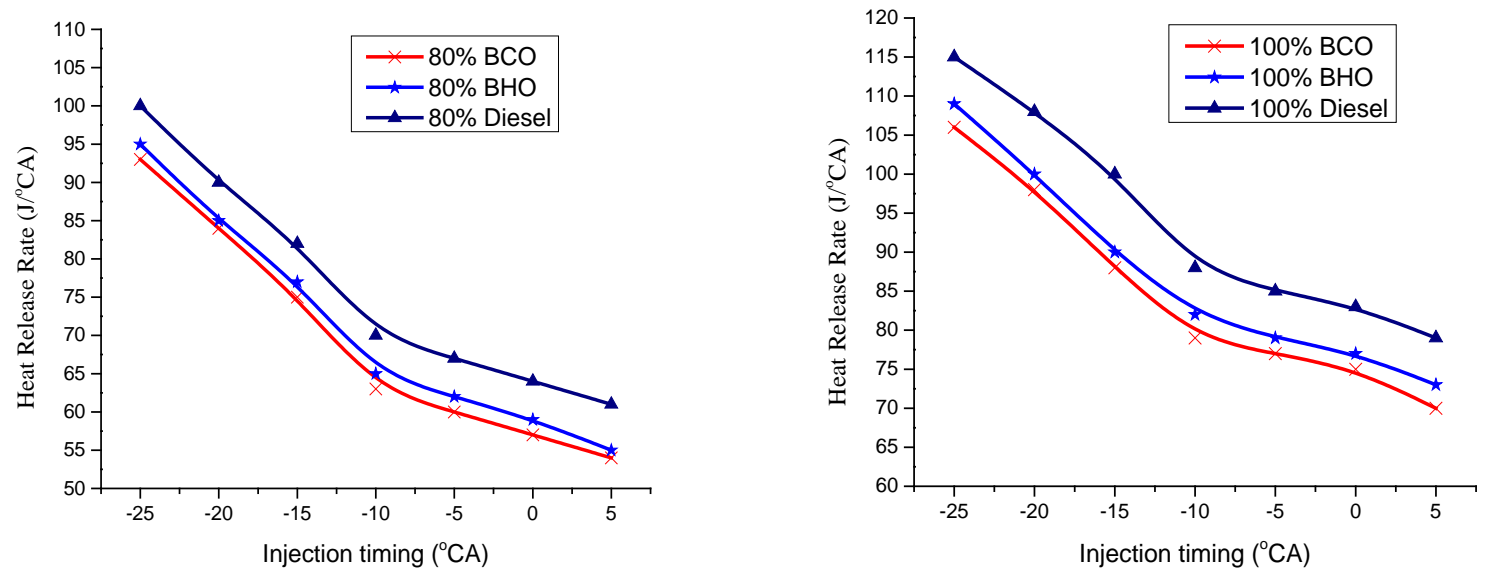

Figure 10. Variation in the HRR at different fuel IT at $80 \%$ and $100 \%$ loads

that at advanced fuel IT, the PP and HRR increases due to longer ID. This resulted in higher peak cylinder gas temperature which elevated the engine out $\mathrm{NO}_{\mathrm{x}}$ emission. Similar results were seen in the literature (Mikulski et al., 2016). $\mathrm{NO}_{\mathrm{x}}$ emissions in the engine out gas were lower for BDF operation compared to mineral diesel operation. This is because of lower gas temperature inside the $\mathrm{CC}$ and lower $\mathrm{CN}$ of selected BDF. The $\mathrm{NO}_{\mathrm{x}}$ emission with BDF were lower by about $33 \%$ to $38 \%$ at fuel IT of $10^{\circ}$ CA bTDC for $80 \%$ load and $100 \%$ load compared to CI mode.

\section{Combustion Parameters}

The ID, CD, PP, and HRR variation with $\mathrm{BHO}$ and $\mathrm{BCO}$ for different fuel IT of $25^{\circ} \mathrm{CA}$ bTDC to $5^{\circ} \mathrm{CA}$ aTDC at constant IP of 600 bar is shown in Figures 7 to 10. From Figures 7 and 8, it can be seen that at all fuel ITs $\left(25^{\circ} \mathrm{bTDC}\right.$ to $\left.5^{\circ} \mathrm{aTDC}\right)$ the ID and CD of the BDF were found to be higher than the mineral diesel. Both ID and $\mathrm{CD}$ decreased with retarded IT up to $10^{\circ} \mathrm{bTDC}$ then showed increasing trend. The reason could be the higher gas temperature obtained at retarded IT. From Figures 9 and 10 it can be seen that at all fuel IT ( $25^{\circ} \mathrm{bTDC}$ to $\left.5^{\circ} \mathrm{aTDC}\right)$ the PP and the peak HRR of the BDF were found to be lower than the mineral diesel. PP and peak HRR of the $\mathrm{BDF}$ were lower due to deterioration in preparation of air-fuel mixture observed with such high viscosity and lower volatile fuels. In addition, the lower energy content of the BDF resulted in reduced PP and HRR. The gas PP and HRR were found higher at advanced fuel IT because of increased ID period. Also more fuel available for chemical reaction in the premixed combustion phase could also be responsible for the trend observed. Similar results were reported in the literature (Hayes et al., 1986; Sayin et al., 2009).

\section{Injection Pressure (IP) Optimization for the Diesel, BDF Powered CRDI Engine}

Experiments were conducted on a CRDI engine powered with diesel and two selected BDFs to study the influence of fuel IP on its performance. The fuel IP was varied keeping the fuel IT constant at $10^{\circ} \mathrm{CA}$ bTDC and the engine speed was maintained constant at $1500 \mathrm{rpm}$. A CRDI injector of 6 holes each of $0.2 \mathrm{~mm}$ orifice size was adopted in the study. For the study only two loads were selected $(80 \%$ and $100 \%)$. 

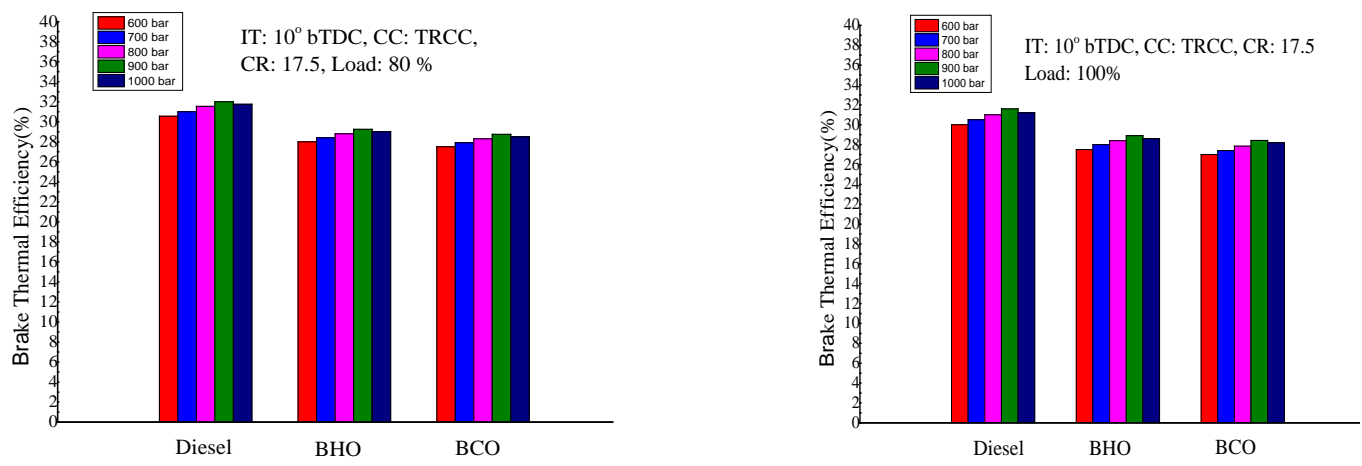

Figure 11. Variation in the BTE with the IP at $80 \%$ and $100 \%$ loads
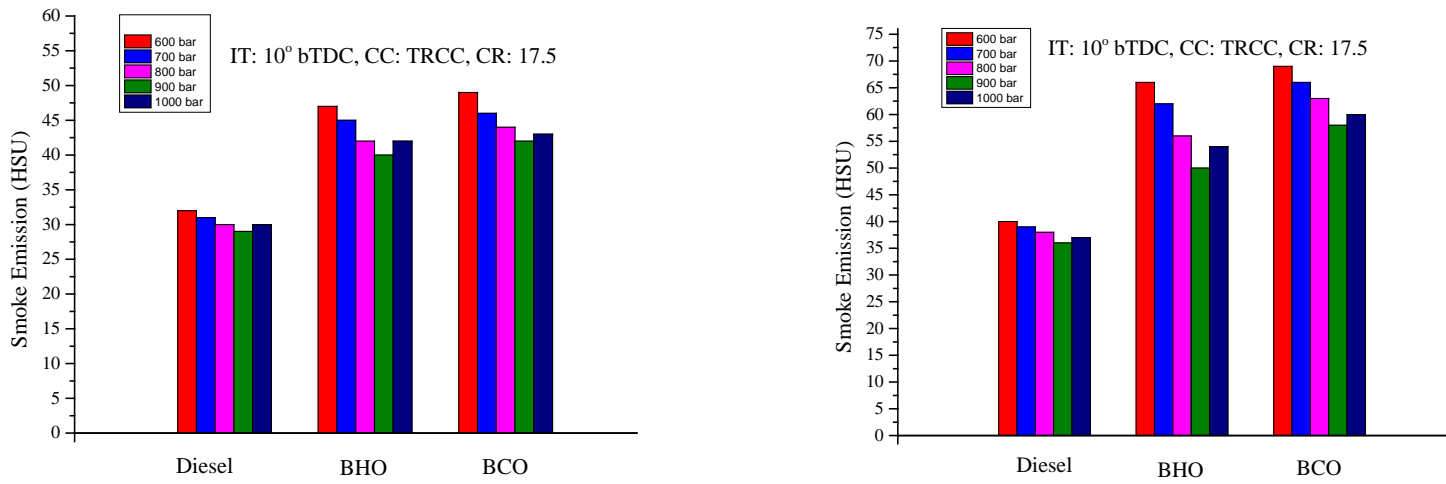

Figure 12. Variation in the smoke emission with the IP at $80 \%$ and $100 \%$ loads

\section{Performance: Brake Thermal Efficiency}

Figure 11 shows the effect of variation in fuel IP on the BTE at different fuel IP (600, 700, 800, 900 and 1000 bar). As the fuel IP was increased, the BTE of the engine increased up to IP of 900 bar then it showed decreasing trend as shown in Figure 9. Improved atomization resulted in homogeneous mixture and reduced ID at higher pressure up to 900 bar. However at fuel IP of 1000 bar BTE decreased slightly due to increased wall wetting. The higher fuel dispersion and penetration at higher fuel IP could also be the reason for higher BTE. Similar results were seen in the literature (Lee and Park, 2002; Leung et al., 2006). Amongst all the fuel IP used for the study, the maximum BTE was obtained at IP of 900 bar. The BTE were lower for both BDF compared to mineral diesel. Lower CN, higher FFA and lower volatility of the BDF injected resulted in to later SOC. The peak HRR for BDF were lower compared to that of mineral diesel under the same engine operating conditions. Maximum BTE was achieved with $\mathrm{BHO}$ and $\mathrm{BCO}$ and were lower by $6.4 \%$ and $8 \%$ respectively at $80 \%$ load and IP of 900 bar compared to the CI mode. At 100\% load slight reduction in BTE by $1.5 \%$ was seen for all fuels.

\section{Emissions: Smoke Emission}

Figure 12 depicts the effect of variation in fuel IP on the smoke emission at $80 \%$ and $100 \%$ loads. The smoke emission were lower at higher fuel IP of $900 \mathrm{bar}$ and it might be due to enhanced atomization resulting in complete combustion. Biodiesels have heavier molecular structure due to their higher viscosity. The improper air fuel mixture formed resulted into higher smoke emissions. The lowest smoke level achieved at a fuel IP of 900 bar. The smoke emissions of the CRDI mode with BDF were higher by $26-32 \%$ at $80 \%$ and $100 \%$ load compared to CI mode.

\section{$H C$ and $C O$ emissions}

Figures 13 and 14 shows the effect of change in fuel IP on the engine out $\mathrm{HC}$ and $\mathrm{CO}$ emissions at $80 \%$ and $100 \%$ loads. At higher fuel IP the decreasing trend of engine out HC and CO emissions for all fuels resulted and might be due to complete combustion of the injected fuels on account of better atomization and mixing with air. Good ignition qualities and higher oxygen content of both BDF produced lower engine out HC and CO emissions but these were slightly higher than mineral diesel. The HC emission achieved with BDF were higher by $8 \%$ to $14 \%$ at $80 \%$ and $100 \%$ load compared to CI mode. Similarly the CO emission with BDF were higher by $11 \%$ to $23 \%$ 

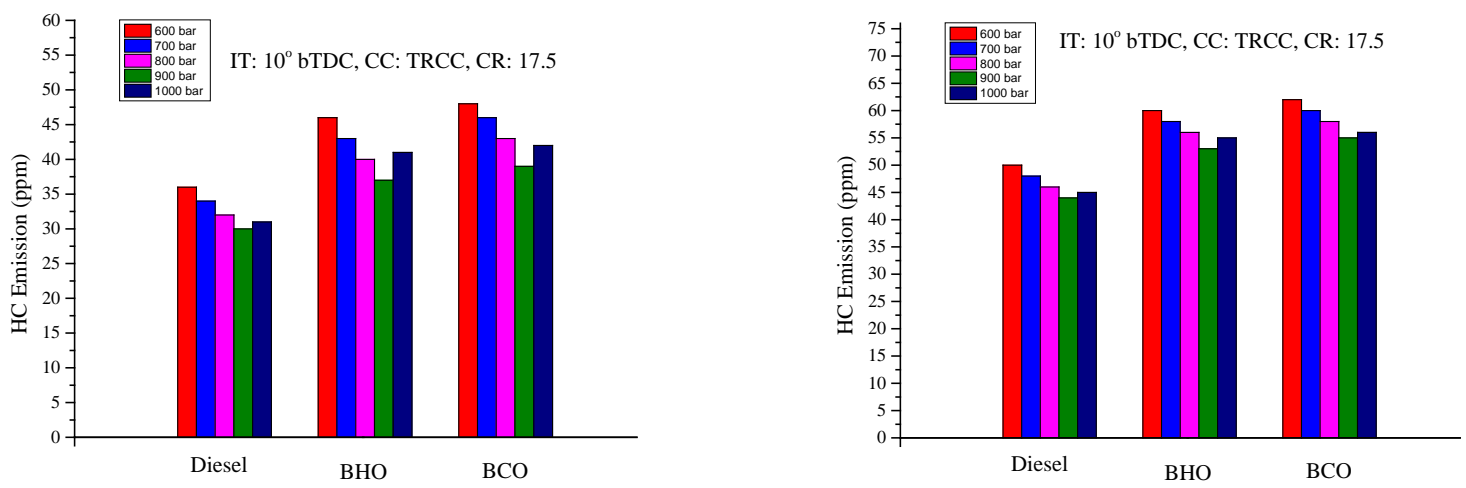

Figure 13. Variation in the HC emission with the IP at $80 \%$ and $100 \%$ loads
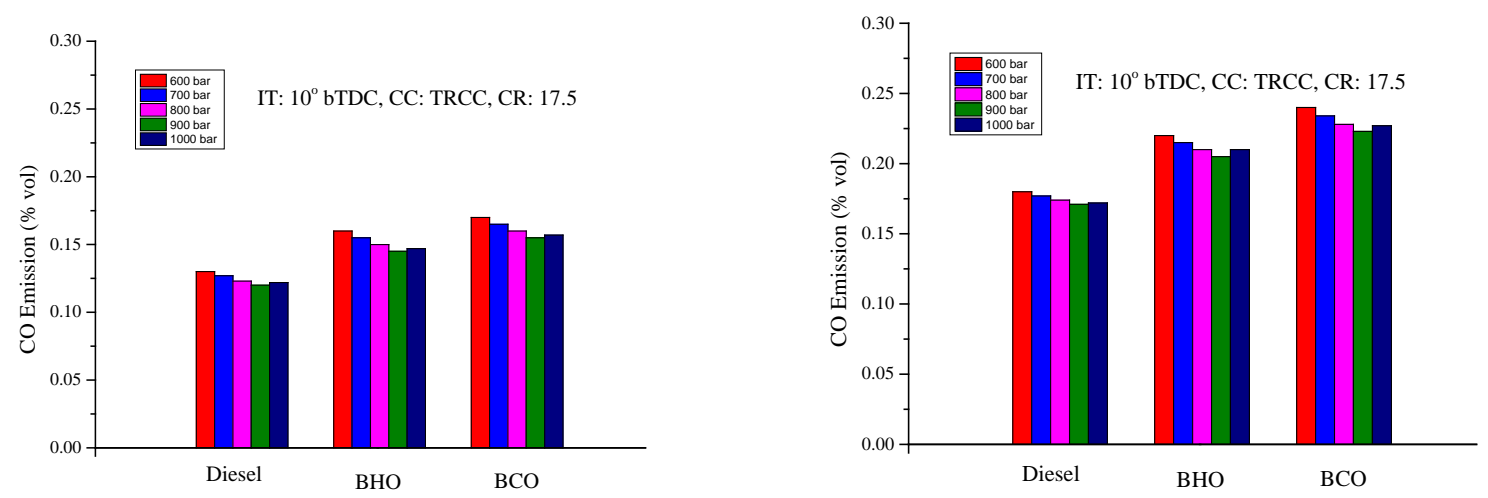

Figure 14. Variation in the CO emission with the IP at $80 \%$ and $100 \%$ loads
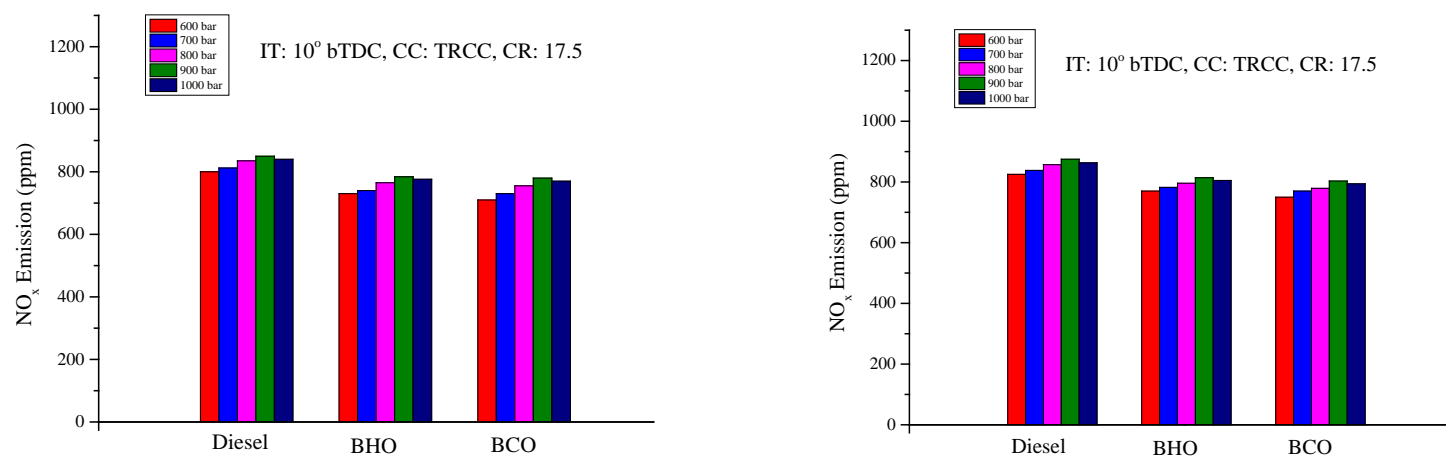

Figure 15. Variation in the $\mathrm{NO}_{\mathrm{x}}$ emission with the IP at $80 \%$ and $100 \%$ loads

at $80 \%$ load and at $100 \%$ load compared to CI mode. Also the lower values of BTE with BDF were responsible for these trend observed. A fuel IP of 1000 bar resulted in slightly higher engine out HC and CO emissions due to increased wall wetting. At higher IP the fuels pray reaches CC wall quickly as it penetrates through longer distance.

\section{$N O_{x}$ Emissions}

The change in engine out $\mathrm{NO}_{\mathrm{x}}$ emission in the exhaust gas of the engine with fuel IP is shown in Figure 15 at $80 \%$ and $100 \%$ loads. The enhanced combustion rate due to better fuel atomization and dispersion increased cylinder gas temperature in the cycle at higher fuel IP. Diesel yielded higher engine out NOx emission compared to $\mathrm{BD}$ fuels as these have higher viscosity and lower energy density. The increased fuel dispersion and smaller droplet size obtained due to higher fuel IP led to better air fuel mixing which decreased ID. This increased the HRR and resulted into higher in-cylinder gas temperature which increased the engine out NOx emissions. The BDFs showed reduced premixed combustion and hence slightly lower engine out $\mathrm{NO}_{\mathrm{x}}$ emissions as compared to mineral diesel. The lower adiabatic flame temperature and $\mathrm{CN}$ of $\mathrm{BDF}$ resulted into lower level of engine out $\mathrm{NO}_{\mathrm{x}}$ emissions. The NOx emission achieved in the CRDI mode with BDF were lower by $26 \%$ to $32 \%$ at $80 \%$ and 

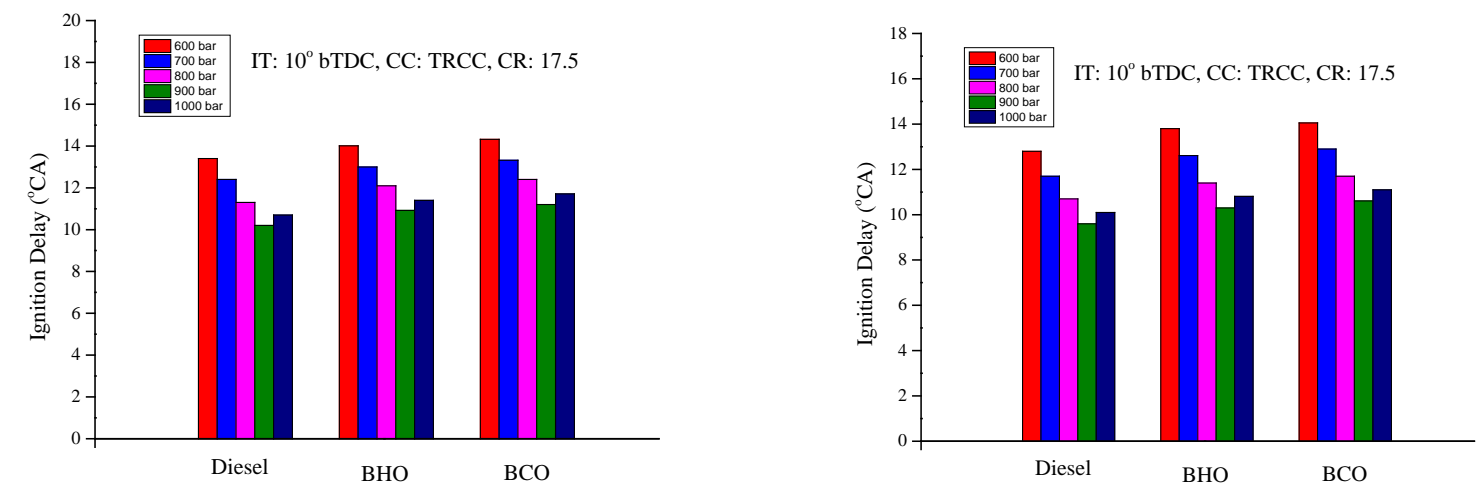

Figure 16. Variation in the ID with the IP at $80 \%$ and $100 \%$ loads
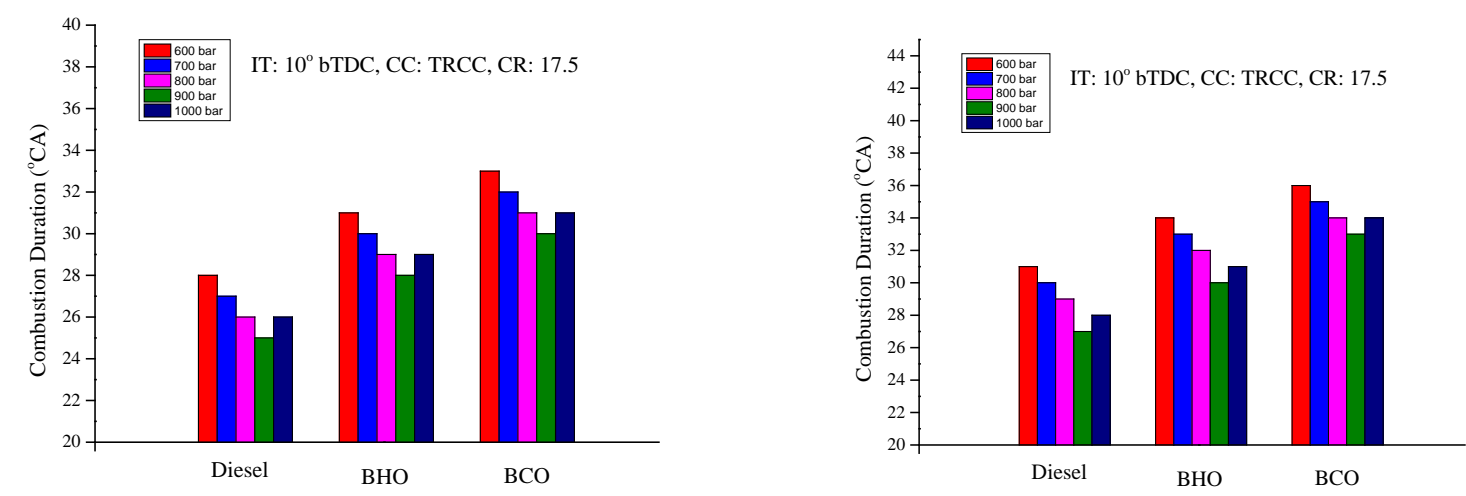

Figure 17. Variation in the CD with the IP at $80 \%$ and $100 \%$ loads
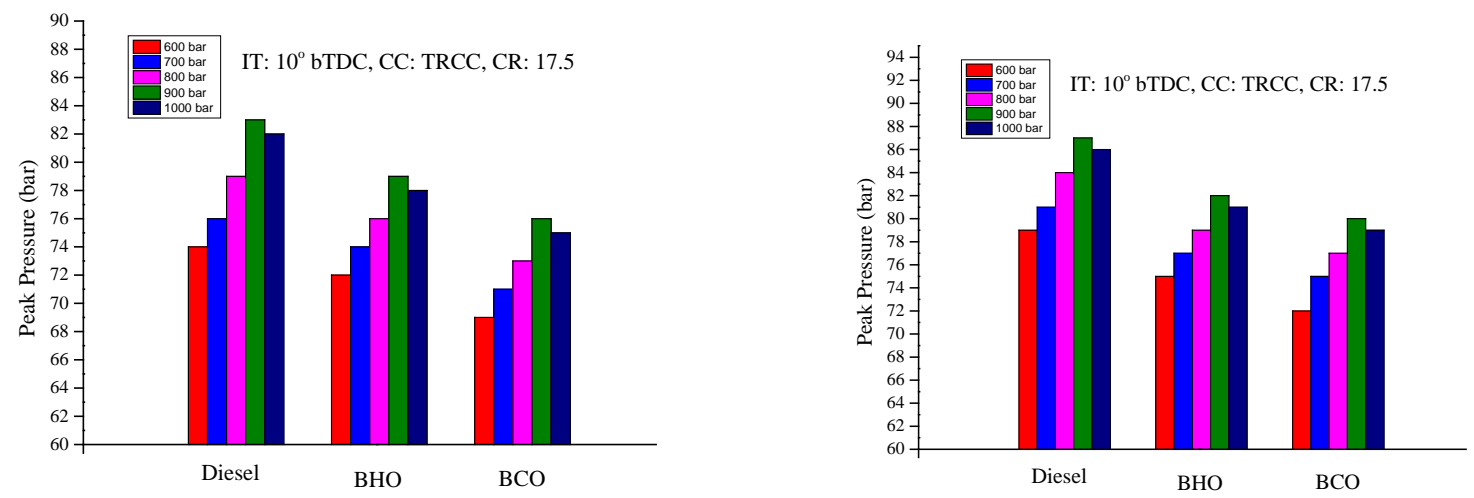

Figure 18. Variation in the PP with the IP at $80 \%$ and $100 \%$ loads

$100 \%$ load compared to $\mathrm{CI}$ mode. $\mathrm{NO}_{\mathrm{x}}$ emission of $\mathrm{BHO}$ was slightly higher as compared to $\mathrm{BCO}$ due to higher in cylinder temperature that prevailed and HRR.

\section{Combustion Parameters:}

The ID, CD, PP and peak HRR variation for CRDI engine powered with diesel and BDF at different fuel IP and at a constant fuel IT of $10^{\circ} \mathrm{CA}$ bTDC is shown in Figure 16 and Figure 19. PP increased with increase in fuel IP till 900 bar beyond which it reduced. Similar trends could be seen for peak HRR as shown in Figure 16. Better fuel atomization at higher IP and reduced ID resulted in enhanced burning of injected fuels there by the increase in PP and HRR was observed. Similar results could be seen in the literature (Grimaldi et al., 2002; Leung et al., 2006; Ozsezen et al., 2008). Slight decrease in PP and HRR at 1000 bar IP could be due to fuel entering in to the crevices escaping the main combustion and also could be due to delayed injection negating the performance. The $\mathrm{BDF}$ is more viscous which creates higher friction around the injector needle there by indicating slow needle-lift 

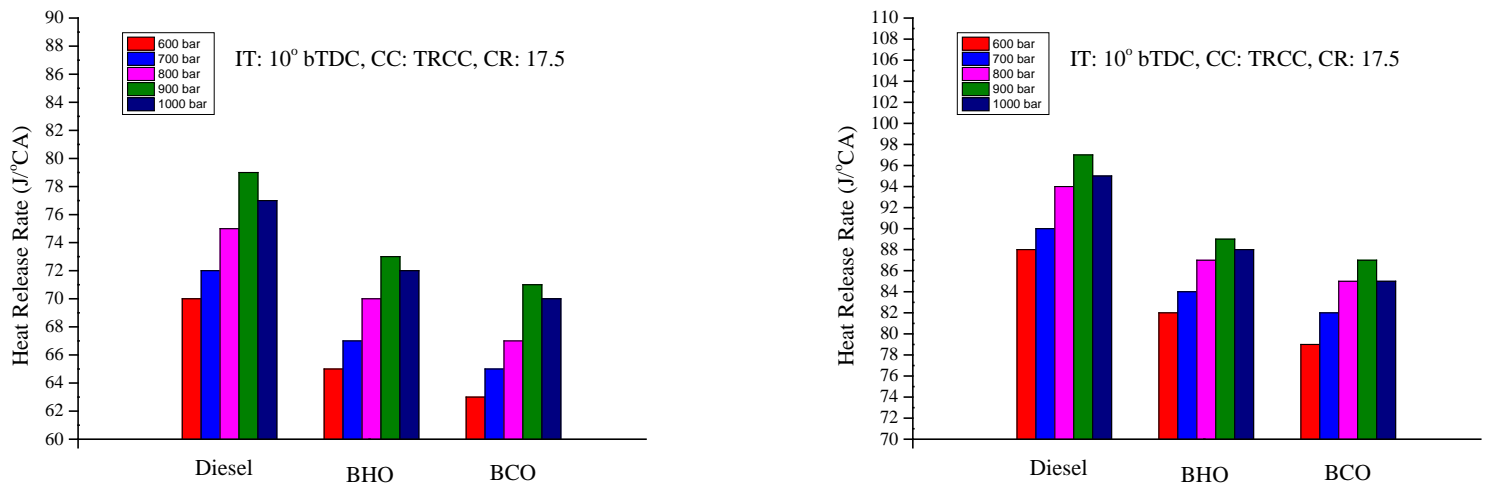

Figure 19. Variation in the HRR with the IP at $80 \%$ and $100 \%$ loads

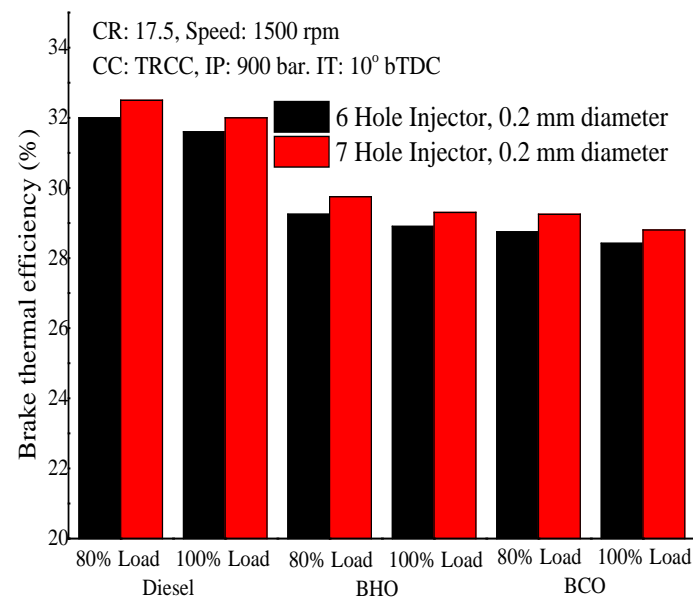

Figure 20. Comparison of the BTE of the CRDI engine using6 and 7 hole injectors

movement with longer injection delay. At the same SOI of fuel, increased fuel IP changed the heat release profile that is higher fuel IP led to SOC quite early in the cycle and also found higher with narrowed heat release peak.

\section{Effect of Number of Injector Holes on the Performance, Emission and Combustion Characteristics of CRDI Engine Powered with Diesel and Biodiesels}

The experimental tests were conducted on CRDI engine fuelled with diesel, BHO and BCO at 80 and $100 \%$ load to investigate the effect of number of injector holes on its performance. The results of 6 and 7 hole injectors of single injection CRDI operation are discussed in the following section. Both 6 and 7 hole injectors had the orifice diameter of $0.2 \mathrm{~mm}$. The injection of fuel was carried at an IT of $10^{\circ} \mathrm{bTDC}$ and IP of $900 \mathrm{bar}$.

\section{Performance: Brake Thermal Efficiency}

Figure 20 shows the comparison of the BTE of the CRDI engine with all fuels for 6 and 7 hole injectors. Improved BTE with 7 hole injector compared to 6 hole for all the fuels and injection strategies are shown in Figure 20. Lower penetration of fuels injected with former reduced the wall impingement as mass low rate per hole gets reduced when number of holes increased from 6 to 7. More quantity of fuel participated in combustion and higher percentage vaporization was resulted with 7 hole nozzle and could be the other reasons for higher BTE. Lower $\mathrm{CN}$, higher viscosity, lower volatility of biodiesels led to poor atomization compared to diesel which resulted in lowered BTE compared to diesel.

\section{Emissions: Smoke Emission}

Figure 21 depicts the comparison of smoke emissions of CRDI engine operation with 6 and 7 hole injectors. Lower smoke emissions with 7 hole injector compared to 6 hole for all the fuels and injection strategies were obtained. Reduced wall impingement and complete combustion of fuel might be the reasons for lowered smoke emissions with 7 hole nozzle. Higher percentage vaporization with 7 hole nozzle could be another reason for decreased smoke emission. BDF showed higher smoke emissions compared to mineral diesel fuel due to their 


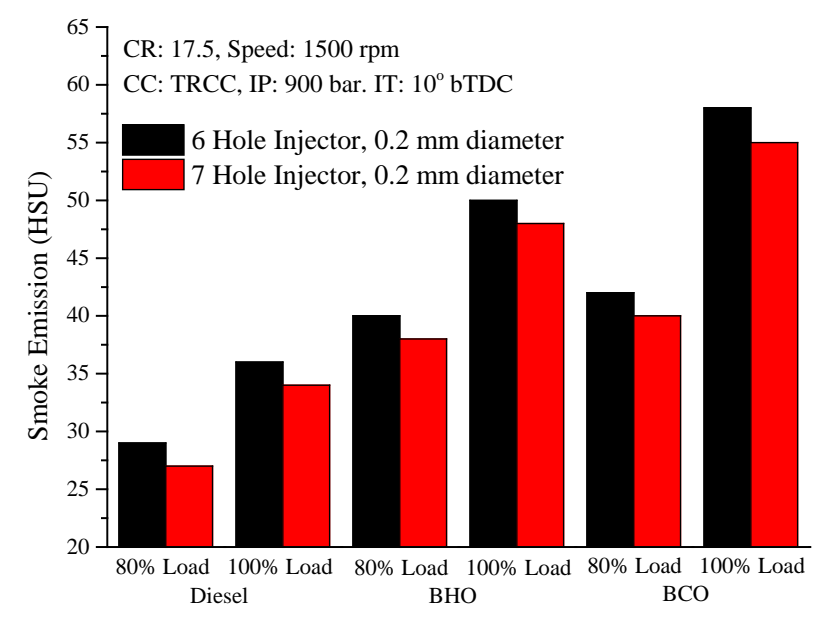

Figure 21. Comparison of the smoke emission of the CRDI engine using 6 and 7 hole injectors

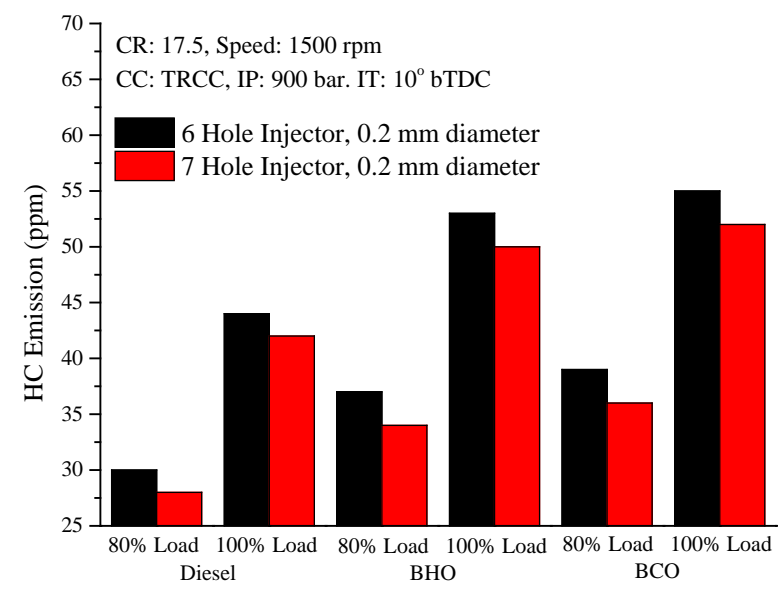

Figure 22. Comparison of the HC emission of the CRDI engine using 6 and 7 hole injectors

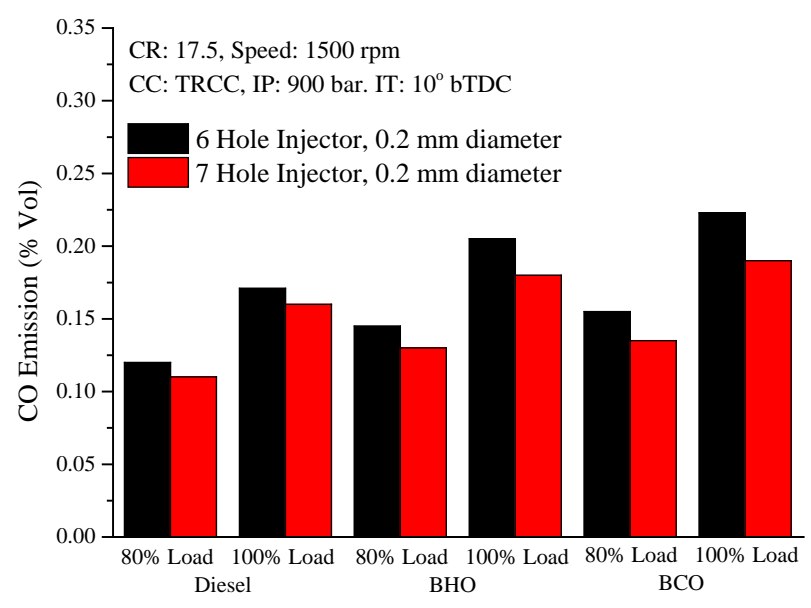

Figure 23. Comparison of the CO emission of the CRDI engine using 6 and 7 hole injectors

lower CN, higher viscosity with lower volatility character that led to poor atomization the IP being same for all fuels. The smoke emission reduced by $20 \%$ to $26 \%$ in diesel and biodiesel powered CRDI engine as compared to $\mathrm{CI}$ mode. $\mathrm{BCO}$ showed slightly higher smoke emission as compared to $\mathrm{BHO}$ due to its lower burning rate. 


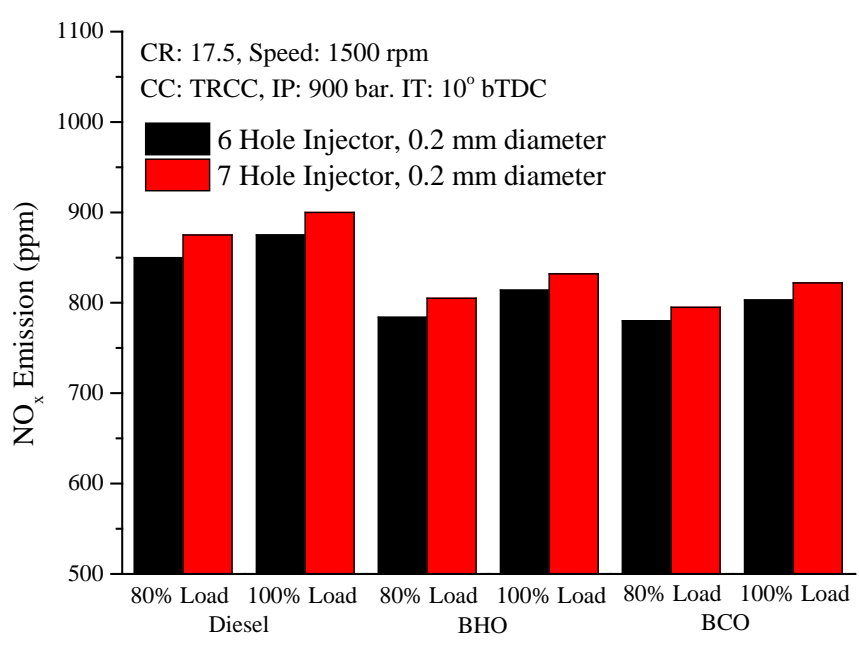

Figure 24. Comparison of the $\mathrm{NO}_{\mathrm{x}}$ emission of the CRDI engine using 6 and 7 hole injectors

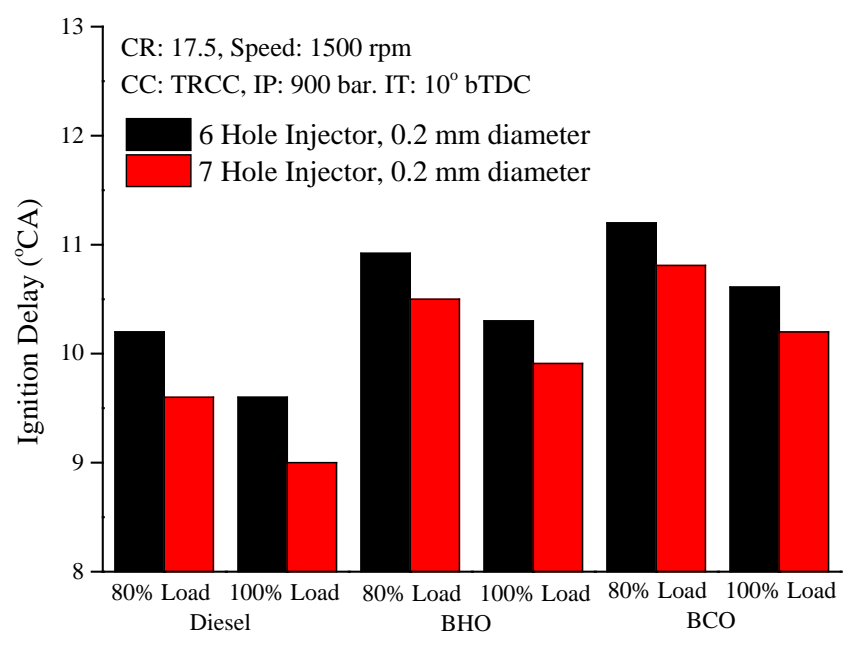

Figure 25. Comparison of the ID of the CRDI engine using 6 and 7 hole injectors

\section{$H C$ and $C O$ Emissions}

Figures 22 and 23 indicates the comparison of the engine out $\mathrm{HC}$ and $\mathrm{CO}$ emissions of CRDI engine operation with 6 and 7 hole injectors. The CRDI operation resulted in lower HC and CO emissions with 7 hole injector compared to 6 hole for all the fuels and injection strategies. Lower fuel penetration distance reduces the wall impingement as mass flow rate per hole gets reduced. A larger quantity of fuel participated in combustion and higher percentage vaporization that resulted with 7 hole nozzle and could be other reasons for lower trend of HC and $\mathrm{CO}$ emission. Biodiesels showed higher $\mathrm{HC}$ and $\mathrm{CO}$ emissions compared to diesel fuel due to their lower $\mathrm{CN}$, higher viscosity with lower volatility character that led to poor atomization compared to diesel though the IP was same for all fuels.

\section{$N O_{x}$ Emissions}

Figure 24 illustrates the comparison of engine out NOx emissions of CRDI engine operation with injector of6 and 7 holes. The CRDI operation resulted in higher NOx emissions with 7 hole injector compared to 6 hole for all the fuels and injection strategies adopted. Lower penetration distance obtained with the former further reduces the wall impingement as mass flow rate per hole gets reduced and more fuel participate in combustion process and this could increase the in cylinder gas temperature, PP and HRR and hence the $\mathrm{NO}_{\mathrm{x}}$ emission increased. Higher percentage vaporization with 7 hole nozzle could be another reason for higher $\mathrm{NO}_{\mathrm{x}}$ emission. BDF showed lower $\mathrm{NO}_{\mathrm{x}}$ emissions compared to mineral diesel due to their lower $\mathrm{CN}$, higher viscosity and lower volatility which led 


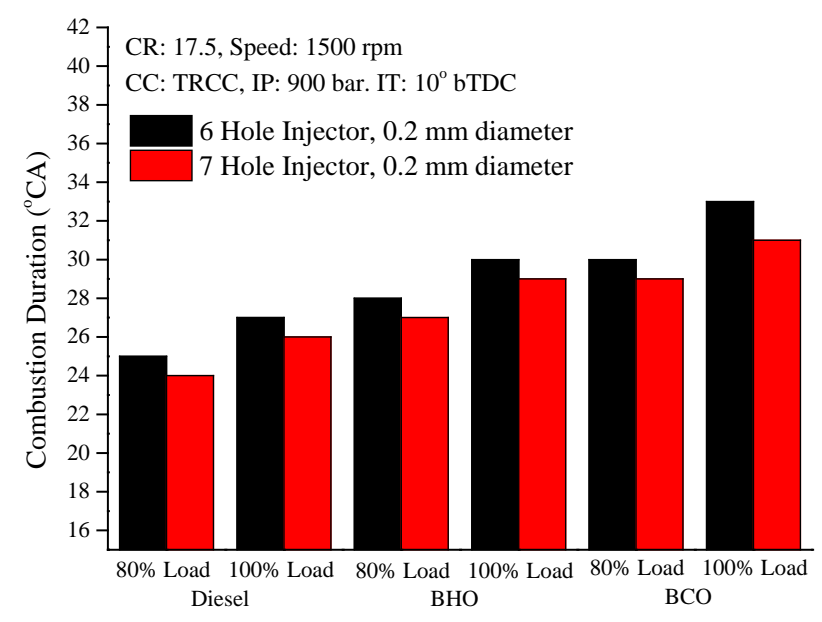

Figure 26. Comparison of the $\mathrm{CD}$ of the CRDI engine using 6 and 7 hole injectors

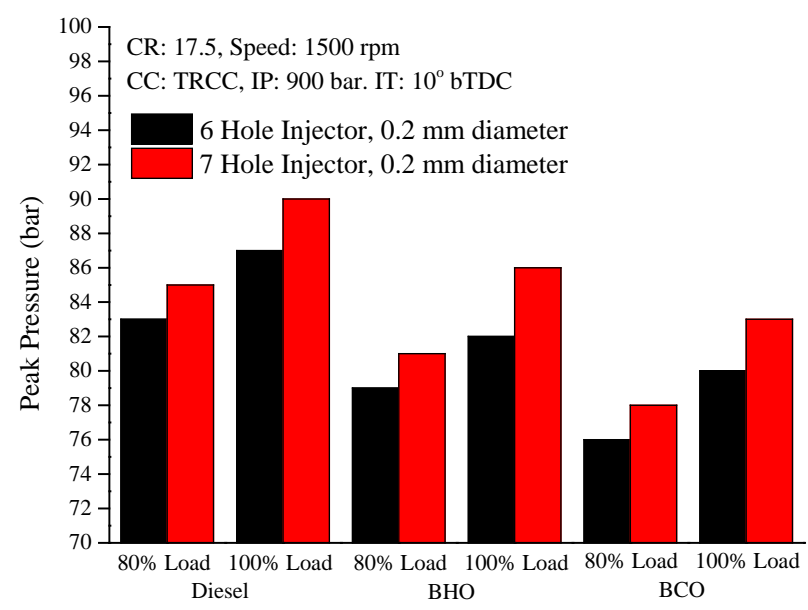

Figure 27. Comparison of the PP of the CRDI engine using 6 and 7 hole injectors

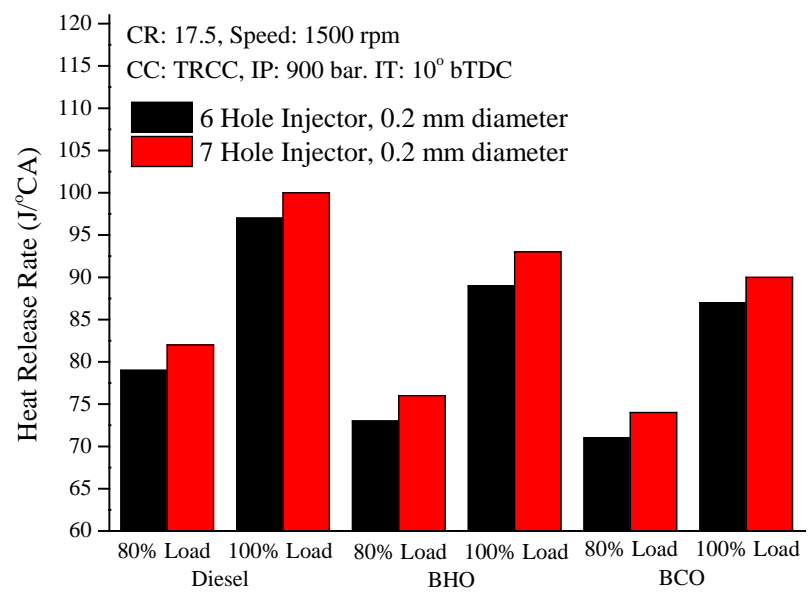

Figure 28. HRR of the CRDI engine using 6 and 7 hole injectors

to poor atomization. NOx reduced by $16 \%$ to $20 \%$ in diesel and biodiesel powered CRDI engine as compared to CI mode. 


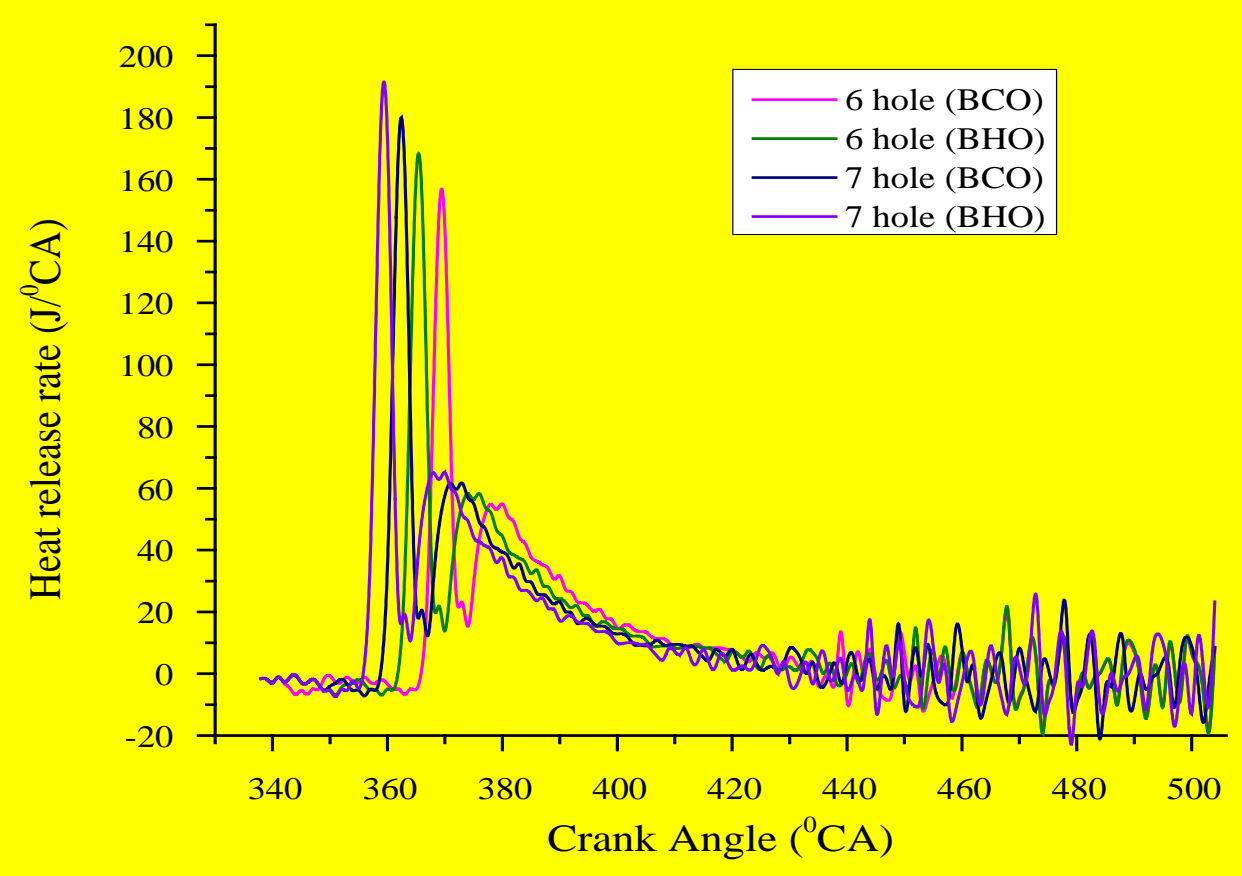

Figure 29. Variation of HRR with crank angle of CRDI engine for 6 and 7 hole injectors using BCO and BHO

\section{Combustion Parameters}

Comparison of ID, CD, PP and Peak HRR of CRDI engine operation with 6 and 7 hole injectors is provided in Figures from 25 to 29 respectively. From the Figures 25 and 26, it can be seen that the ID and CD of the BDF were higher than the diesel at both loads. But the ID found lower at $100 \%$ load compared to $80 \%$ and on the other hand the $\mathrm{CD}$ was higher at 100\% load compared to $80 \%$. Also 7-hole injector resulted in to lower ID and $\mathrm{CD}$ as compared to 6 hole injector for all fuels and could be due to higher gas temperature leading to more homogeneous mixture formation. The diesel and BDF powered CRDI engine with injector of 7 holes yielded $6 \%$ to $11 \%$ lower ID and $15 \%$ to $19 \%$ lower $\mathrm{CD}$ as compared to $\mathrm{CI}$ mode.

From the Figures 27 and 28, it can be seen that the PP and the peak HRR of the BDF were found lower as compared to diesel. The PP and peak HRR of the BDF were lower due to deterioration in preparation of air-fuel mixture as a result of high viscosity and lower volatility of fuels. In addition, the lower energy content of the BDF resulted in reduced PP and HRR. A 7 hole injector resulted in to higher PP and HRR as compared to 6 hole injector for all fuels due to better air fuel mixing. Also lower ID allowed more fuel available for chemical reaction in the premixed combustion phase which resulted in higher PP and HRR. The diesel and BDF powered CRDI engine with injector of 7 holes yielded 10\% to $14 \%$ higher PP and HRR as compared to CI mode. The ID and CD of $\mathrm{BCO}$ was higher compared to $\mathrm{BHO}$ but PP and peak HRR were lower which reflects the poor combustion qualities of BCO. Variation of HRR with crank angle is shown in Figure 29. HRR was found to higher for 7 hole injector compared 6 hole injector due to better premixed combustion phase is likely to be more prominent with increased number of holes and this will affect HRR. For the same hole injector, BHO results in higher HRR compared to BCO due to differences in the fuel properties.

\section{CONCLUSIONS}

CI engine was suitably modified to operate with CRDI facility at $1500 \mathrm{rpm}$ using TRCC and injector of 6 and 7 holes with holes of orifice $0.2 \mathrm{~mm}$ diameter each. From the detailed experimental study on CRDI engine powered with diesel and BDF, the following conclusions were drawn:

- The optimum fuel IT and IP for the CRDI engine were $10^{\circ}$ bTDC and 900 bar respectively for all fuels tested.

- The diesel and BDF powered CRDI engine with an injector having 7 holes yielded 5\% to $6 \%$ higher BTE as compared to CI mode. 
- Lowered HC, and CO emissions with 7 holes injector respectively by $15 \%$ to $18 \%$, and $11 \%$ to $16 \%$ as compared to CI mode.

- Smoke emission reduced by $20 \%$ to $26 \%$ while NOx reduced by $16 \%$ to $20 \%$ in diesel and biodiesel powered CRDI engine as compared to CI mode.

- The diesel and BDF powered CRDI engine with an injector of 7 holes yielded $10 \%$ to $14 \%$ higher PP and HRR as compared to CI mode.

- The diesel and BDF powered CRDI engine with injector of 7 holes yielded $6 \%$ to $11 \%$ lower ID and $15 \%$ to $19 \%$ lower CD as compared to CI mode.

- BHO showed better performance in terms of higher BTE and lower emissions except NOx as compared to $\mathrm{BCO}$ due its better combustion qualities. Also combustion characteristics of $\mathrm{BHO}$ were better as compared to BCO.

Overall it can be concluded that the modified CI engine operated in CRDI mode worked satisfactorily with selected BDFs at optimum fuel IT and IP of $10^{\circ}$ bTDC and 900 bar respectively. CRDI engine operation with 7 holes injector yield improved BTE and resulted in a drastic reduction in smoke and NOx emissions as compared to $\mathrm{CI}$ mode. Both BDFs were well suited for CRDI engine operation which can reduce the burden on oil import bill.

\section{NOMENCLATURE}

aTDC - After top dead centre

BDF - Biodiesel fuel

BHO - Honge oil biodiesel

BSFC - Brake specific fuel consumption

bTDC - Before top dead centre

BTE - Brake thermal efficiency

CA - Crank angle

CC - Combustion chamber

$\mathrm{CD}$ - Combustion duration

$\mathrm{CI}-$ Compression ignition

$\mathrm{CN}$ - Cetane number

$\mathrm{CO}$ - Carbon monoxide

CRDI - Common rail direct injection

ECU - Electronic control unit

EGR - Exhaust gas recirculation

FFA - Free fatty acid

$\mathrm{HC}$ - Hydrocarbon

HCC - Hemispherical combustion chamber

HRR - Heat release rate

ID - Ignition delay

IMEP - Indicated mean effective pressure

IP - Fuel injection pressure

ISFC - Indicated specific fuel consumption

IT - Fuel injection timing

NOx - Oxides of nitrogen

PP - Peak pressure

SI - Spark ignition

SMD - Sauter mean diameter

SOC - Start of combustion

SOI - Start of fuel injection

TDC - Top dead centre

TRCC - Toriodal re-entrant combustion chamber

\section{REFERENCES}

Agarwal, A. K., Dhar, A., Gupta, J. G., Kim, W. I., Choi, K., Lee C. S. and Park, S. (2015). Effect of fuel injection pressure and injection timing of Karanja biodiesel blends on fuel spray, engine performance, emissions and 
combustion characteristics. Energy Conversion and Management, 91, 302-314. https://doi.org/10.1016/j.enconman.2014.12.004

Armas, O., Hernandez, J. J. and Cardenas, M. D. (2006). Reduction of diesel smoke opacity from vegetable oil methyl ester during transient operation. Fuel, 85, 2427-2438. https://doi.org/10.1016/j.fuel.2006.04.016

Bakar, R. A., Ismail, S. and Ismail, A. R. (2008). Fuel injection pressure effect on performance of direct injection diesel engines based on experiment. Am J Appl Sci, 5(3), 197-202. https://doi.org/10.3844/ajassp.2008.197.202

Can, O., Celikten, I. and Usta, N. (2004). The effect of biodiesel, ethanol and diesel fuel blends on the performance and exhaust emission in a DI diesel engine. Energy Conversion and Management, 45, 2429-2440. https://doi.org/10.1016/j.enconman.2003.11.024

Du, J., Sun, W., Guo, L., Xiao, S., Tan, M., Li, G. and Fan, L. (2015). Experimental study on fuel economies and emissions of direct-injection premixed combustion engine fueled with gasoline/diesel blends. Energy Conversion and Management, 100, 300-309. https:/ / doi.org/10.1016/j.enconman.2015.04.076

Grimaldi, C. N., Postrioti, L. and Battistoni, M. (2002). Common Rail HSDI engine combustion and emissions with fuel. Bio-derived Fuel Blends, 2002-01-0865, 1453-1460.

Hayes, T. K., Savage, L. D. and Sorenson, S. C. (1986). Cylinder pressure data acquisition and heat release analysis on a personal computer. $S A E$ paper 860029. https://doi.org/10.4271/860029

Hwang, J., Qi, D., Jung, Y. and Bae, C. (2014). Effect of injection parameters on the combustion and emission characteristics in a common-rail direct injection diesel engine fueled with waste cooking oil biodiesel. Renewable Energy, 63, 9-17. https://doi.org/10.1016/j.renene.2013.08.051

Hohenberg, G. F. (1979). Advanced approaches for heat transfer calculations. SAE paper 790825. https:// doi.org/10.4271/790825

Kim, H. and Choi, B. (2009). The effect of biodiesel and bio ethanol blended diesel fuel on nanoparticles and exhaust emissions from CRDI diesel engine. Renewable Energy, 35, 157-163. https://doi.org/10.1016/j.renene.2009.04.008

Labecki, L., Cairns, A., Xia, J., Megaritis, A., Zhao, H. and Ganippa, L. C. (2012). Combustion and emission of rapeseed oil blends in diesel engine. Applied Energy, 95, 139-246. https://doi.org/10.1016/j.apenergy.2012.02.026

Labecki, L. and Ganippa, L. C. (2012). Effects of injection parameters and EGR on combustion and emission characteristics of rapeseed oil and its blends in diesel engines. Fuel, 81, 2417-2423. https://doi.org/10.1016/j.fuel.2012.03.029

Lee, C. S. and Park, S. W. (2002). An experimental and numerical study on fuel atomization characteristics of high pressure diesel injection sprays. Fuel, 81, 2417-2423. https://doi.org/10.1016/S0016-2361(02)00158-8

Leung, D., Luo, Y. and Chan, T. (2006). Optimization of exhaust emissions of a diesel engine fuelled with biodiesel. Energy Fuels, 20, 1015-1023. https://doi.org/10.1021/ef050383s

Mikulski, M., Duda, K. and Wierzbicki, S. (2016). Performance and emissions of a CRDI diesel engine fuelled with swine lard methyl esters-diesel mixture. Fuel, 164, 206-219. https://doi.org/10.1016/j.fuel.2015.09.083

Monyem, A., Gerpen, J. H. and Canakci, M. (2001). The effect of timing and oxidation on emissions from biodiesel-fueled engines. Trans AS AE, 44, 35-42. https://doi.org/10.13031/2013.2301

Narayana, R. J., Ramesh, A. and Usta, N. (2006). Parametric studies for improving the performance of a jatropha oil-fuelled compression ignition engine. Renewable Energy, 31, 1994-2016. https://doi.org/10.1016/j.renene.2005.10.006

Ozsezen, A. N., Canaki, M. and Sayin, C. (2008). Effects of biodiesel from used frying palm oil on the performance, injectionand combustion characteristics of an indirect injection diesel engine. Energy Fuels, 22, 1297-305. https://doi.org/10.1021/ef700447z

Puhan, S., Jegan, R., Balasubbramanian, K. and Nagarajan, G. (2009). Effect of injection pressure on performance, emission and combustion characteristics of high linolenic linseed oil methyl ester in a DI diesel engine. Renewable Energy, 34(5), 1227-33. https://doi.org/10.1016/j.renene.2008.10.001

Sayin, C., Ilhan, M., Canakci, M. and Gumus, M. (2009). Effect of injection timing on the exhaust emissions of a diesel engine using diesel methanol blends. Renew Energy, 34, 1261-1269. https://doi.org/10.1016/j.renene.2008.10.010

Senatore, A., Cardone, M. and Buono, D. (2008). Combustion Study of a Common Rail Diesel Engine Optimized to be Fueled with Biodiesel. Energy \& Fuels, 22(3). https://doi.org/10.1021/ef7004749

Ye, P. and Boehman, A. L. (2010). Investigation of the impact of engine injection strategy on the biodiesel NOx effect with a common-rail turbocharged direct injection diesel engine. Energy Fuels, 24, 4215-25. https://doi.org/10.1021/ef1005176 